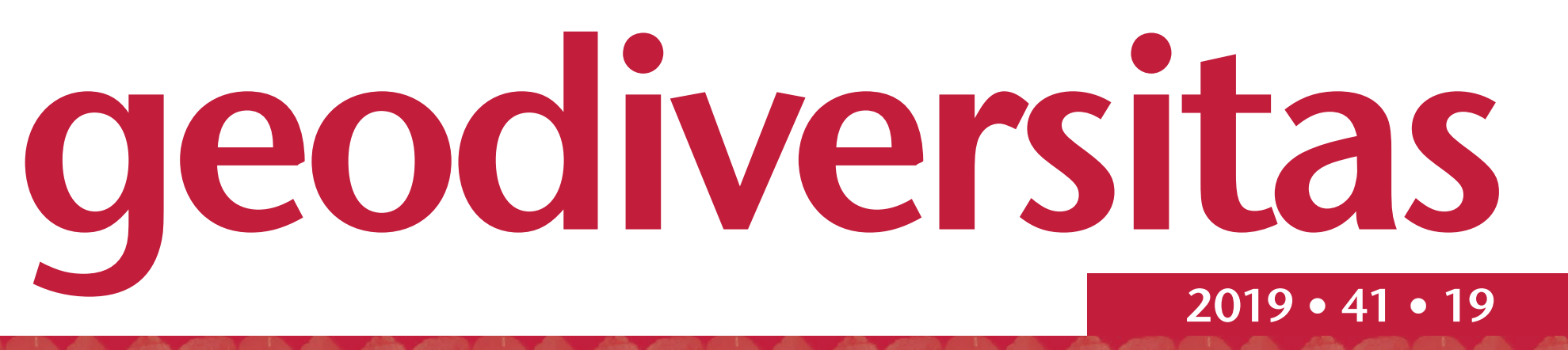

Asterolepis alticristata n. sp. (Antiarchi) from the Upper Devonian (Frasnian) of Nunavut, Canada, and a report on the antiarch diversity of the Fram Formation

Jason P. DOWNS, Edward B. DAESCHLER, Nathanael LO, Emily N. CAREY \& Neil H. SHUBIN 
DiRECTEUR DE LA PUBLICATION: Bruno David,

Président du Muséum national d'Histoire naturelle

RÉdACTEUR EN CHEF / EDITOR-IN-CHIEF: Didier Merle

ASSISTANTS DE RÉDACTION / AsSISTANT EDITORS: Emmanuel Côtez (geodiv@mnhn.fr); Anne Mabille

Mise EN PAGE / PAGE LAYOUT: Emmanuel Côtez

COMITÉ SCIENTIFIQUE / SCIENTIFIC BOARD:

Christine Argot (MNHN, Paris)

Beatrix Azanza (Museo Nacional de Ciencias Naturales, Madrid)

Raymond L. Bernor (Howard University, Washington DC)

Alain Blieck (chercheur CNRS retraité, Haubourdin)

Henning Blom (Uppsala University)

Jean Broutin (UPMC, Paris)

Gaël Clément (MNHN, Paris)

Ted Daeschler (Academy of Natural Sciences, Philadelphie)

Bruno David (MNHN, Paris)

Gregory D. Edgecombe (The Natural History Museum, Londres)

Ursula Göhlich (Natural History Museum Vienna)

Jin Meng (American Museum of Natural History, New York)

Brigitte Meyer-Berthaud (CIRAD, Montpellier)

Zhu Min (Chinese Academy of Sciences, Pékin)

Isabelle Rouget (UPMC, Paris)

Sevket Sen (MNHN, Paris)

Stanislav Štamberg (Museum of Eastern Bohemia, Hradec Králové)

Paul Taylor (The Natural History Museum, Londres)

COUVERTURE / COVER:

Asterolepis alticristata n. sp., NUFV 897, holotype, anterior median dorsal plate in visceral view.

Geodiversitas est indexé dans / Geodiversitas is indexed in:

- Science Citation Index Expanded (SciSearch ${ }^{\circledR}$ )

- ISI Alerting Services ${ }^{\circledR}$

- Current Contents ${ }^{\circledR}$ / Physical, Chemical, and Earth Sciences ${ }^{\circledR}$

- Scopus ${ }^{\circledR}$

Geodiversitas est distribué en version électronique par / Geodiversitas is distributed electronically by:

- BioOne ${ }^{\circledR}$ (http://www.bioone.org)

Les articles ainsi que les nouveautés nomenclaturales publiés dans Geodiversitas sont référencés par / Articles and nomenclatural novelties published in Geodiversitas are referenced by:

- ZooBank ${ }^{\circledR}$ (http://zoobank.org)

Geodiversitas est une revue en flux continu publiée par les Publications scientifiques du Muséum, Paris Geodiversitas is a fast track journal published by the Museum Science Press, Paris

Les Publications scientifiques du Muséum publient aussi / The Museum Science Press also publish:

Adansonia, Zoosystema, Anthropozoologica, European Journal of Taxonomy, Naturae, Cryptogamie sous-sections Algologie, Bryologie, Mycologie.

Diffusion - Publications scientifiques Muséum national d'Histoire naturelle

CP $41-57$ rue Cuvier F-75231 Paris cedex 05 (France)

Tél. : 33 (0)1407948 05 / Fax: 33 (0)14079 3840

diff.pub@mnhn.fr / http://sciencepress.mnhn.fr

(C) Publications scientifiques du Muséum national d'Histoire naturelle, Paris, 2019

ISSN (imprimé / print): 1280-9659/ ISSN (électronique / electronic): 1638-9395 


\title{
Asterolepis alticristata n. sp. (Antiarchi) from the Upper Devonian (Frasnian) of Nunavut, Canada, and a report on the antiarch diversity of the Fram Formation
}

\author{
Jason P. DOWNS \\ Delaware Valley University, Department of Biology, Doylestown, Pennsylvania 18901 (United States) \\ and Academy of Natural Sciences of Drexel University, Department of Vertebrate Biology, \\ 1900 Benjamin Franklin Parkway, Philadelphia, Pennsylvania 19103 (United States) \\ jason.downs@delval.edu \\ Edward B. DAESCHLER \\ Academy of Natural Sciences of Drexel University, Department of Vertebrate Biology, \\ 1900 Benjamin Franklin Parkway, Philadelphia, Pennsylvania 19103 (United States) \\ ebd29@drexel.edu \\ Nathanael LO \\ Swarthmore College, Department of Biology, \\ 500 College Avenue, Swarthmore, Pennsylvania 19081 (United States) \\ nathklo@gmail.com \\ Emily N. CAREY \\ Academy of Natural Sciences of Drexel University, Department of Vertebrate Biology, \\ 1900 Benjamin Franklin Parkway, Philadelphia, Pennsylvania 19103 (United States) \\ enc44@drexel.edu
}

Neil H. SHUBIN

University of Chicago, Department of Organismal Biology and Anatomy, 1027 E. 57th Street, Chicago, Illinois 60637 (United States)

nshubin@uchicago.edu

Submitted on 22 August 2018 | accepted on 9 May 2019 | published on 17 October 2019

KEY WORDS Antiarchi, Asterolepidae, Asterolepis, Fram Formation,
Frasnian, Frasnian,
Nunavut, new species.

Downs J. P., Daeschler E. B., Lo N., Carey E. N. \& Shubin N. H. 2019. - Asterolepis alticristata n. sp. (Antiarchi) from the Upper Devonian (Frasnian) of Nunavut, Canada, and a report on the antiarch diversity of the Fram Formation. Geodiversitas 41 (19): 679-698. https://doi.org/10.5252/geodiversitas2019v41a19. http://geodiversitas.com/41/19

\section{ABSTRACT}

A large collection of fossils from the NV2K17 locality, Upper Devonian (Frasnian) Fram Formation, Ellesmere Island, Nunavut, Canada, represents at least two species of Asterolepis. The first, Asterolepis alticristata n. sp., is diagnosed by a tall midline crest that rises sharply from the tergal angle of the anterior median dorsal plate, reaches maximum height at around the position of the lateral corners, and then drops to form a low midline crest along the posterior median dorsal plate. The second species is identified as Asterolepis cf. radiata according to an ornament of radiating rows of conjoined tubercles and ridges on the available thoracic plates (anterior median dorsal, posterior median dorsal, 


\author{
MOTS CLÉS \\ Antiarchi, \\ Asterolépidae, \\ Asterolepis, \\ Formation de Fram,
Frasnien, \\ Frasnien,
Nunavut, \\ espèce nouvelle.
}

and mixilateral). We describe additional antiarch material from the NV2K17 locality, including an anterior median dorsal plate of Bothriolepis sp. indet., and from localities throughout the Fram Formation. The antiarch occurrences in the Fram Formation conform to a possible faunal turnover from one dominated by asterolepidoids low in the formation to one dominated by bothriolepidids high in the Fram Formation. At the NV2K17 locality, in the middle of the Fram Formation, members of the two groups appear together.

\section{RÉSUMÉ}

Asterolepis alticristata n. sp. (Antiarchi) du Dévonien supérieur (Frasnien) du Nunavut, Canada, et un état des lieux de la diversité en antiarches de la Formation de Fram.

Le matériel fossile daté du Frasnien (Formation de Fram, Dévonien supérieur) du site NV2K17 de l'île d'Ellesmere, dans le territoire du Nunavut au Canada, est composé d'au moins deux espèces du genre Asterolepis. La première, Asterolepis alticristata n. sp., est caractérisée par une haute crête médiane qui s'élève nettement de l'angle tergal de la plaque médiane dorsale antérieure, atteint une hauteur maximale au niveau des coins latéraux, pour se réduire à une crête médiane peu élevée sur la plaque médiane dorsale postérieure. La seconde espèce est identifiée comme étant Asterolepis cf. radiata du fait de l'ornementation des plaques thoraciques (médiane dorsale antérieure, médiane dorsale postérieure, et mixilatérale) constituée de tubercules et crêtes organisés en rangées rayonnantes. Nous décrivons ici aussi du matériel complémentaire d'antiarches du site NV2K17, incluant une médiane dorsale antérieure de Bothriolepis sp. indet., ainsi que d'autres localités de la Formation de Fram. La présence d'antiarches dans la Formation de Fram confirme un possible turnover faunistique, avec la présence d'astérolépidoïdes dans le bas de la Formation et de bothriolépidides dans le haut de la Formation. Des membres de ces deux groupes apparaissent conjointement sur le site NV2K17, positionné au milieu de la Formation de Fram.

\section{INTRODUCTION}

Asterolepis is a cosmopolitan group of antiarchs, extinct stem gnathostomes with dermal skeletal armor that surrounds the cranium, thorax, and pectoral appendages. Here we describe new fossil material from the NV2K17 locality (Fig. 1), Upper Devonian (Frasnian) Fram Formation, Ellesmere Island, Nunavut, Canada, that represents at least two species of Asterolepis. Of these two, one is diagnosable to a new species. The new species is represented by parts of the cephalic skeleton (premedian and nuchal plates), dorsal thoracic skeleton (anterior median dorsal, posterior median dorsal, anterior dorsolateral, and mixilateral plates), ventral thoracic skeleton (anterior ventrolateral, posterior ventrolateral, and median ventral plates), and pectoral appendage (dorsal and ventral central 1 plates). The second species, here identified as Asterolepis cf. radiata, is represented by anterior median dorsal, posterior median dorsal, and mixilateral plates. We also present other antiarch fossils from this locality and from elsewhere in the Fram Formation. We provide anatomical descriptions when appropriate and more specific taxonomic assignments when possible.

In addition to the new species described here, Asterolepis is represented by fourteen species with a geographic distribution that includes Russia and the Baltics (type species Asterolepis ornata Eichwald, 1840 sensu Agassiz [1844]; Asterolepis cristata Obruchev, 1933 [a species supported by Moloshnikov 2008, though Karatajūte-Talimaa 1963 and Lyarskaja 1981 consider it synonymous with Asterolepis radiata Rohon, 1899];
Asterolepis dellei Gross, 1940; Asterolepis estonica Gross, 1940; Asterolepis radiata Rohon, 1899; Asterolepis essica Lyarskaja, 1981; Asterolepis syasiensis Lyarskaja, 1981; and Asterolepis? amulensis Lyarskaja, 1981), Scotland (Asterolepis maxima Agassiz, 1844; Asterolepis orcadensis Watson, 1932; and Asterolepis thule Watson, 1932), Greenland (Asterolepis saevesoederberghi Stensiö \& Säve-Söderbergh, 1938), Spitsbergen (Asterolepis scabra Woodward 1891), and New York, United States (Asterolepis chadwicki Wells 1964). Indeterminate species of Asterolepis, or material that compares favorably with Asterolepis, have been additionally reported from Belgium (Gross 1965; Olive 2015); Iran (Janvier 1979); Colombia, South America (Janvier \& Villarroel 2000); New South Wales (Young 1993) and Canning Basin (Young 1987), Australia; southwestern Canada (Elliott et al. 2000); westernUnited States (Elliott \& Petriello 2011; Murphy et al. 1976; Schultze 2010); Siberia (Moloshnikov 2012); and Vietnam (Janvier et al. 2003). A global geographic distribution may be inferred from these occurrences, but the actual alpha-diversity of Asterolepis remains an open question due to a problematic taxonomic history.

In Asterolepis, species diagnoses are almost universally based on body size (e.g., Asterolepis maxima Agassiz, 1844), shape characteristics of the anterior median dorsal plate with particular relevance given to the ratio between cranial width and midline length of the plate (e.g., Asterolepis dellei Gross, 1940; Asterolepis chadwicki Wells, 1964), and/or the superficial ornament of whatever plates are known of the species (e.g., radiating ridges as reflected in the name Asterolepis radiata Rohon, 1899; large tubercles conjoined into ridges 
as reflected in the name Asterolepis scabra Woodward, 1891). Because most Asterolepis species diagnoses are based on small samples of isolated skeletal plates (e.g., Asterolepis dellei Gross, 1940, based on a partial lateral and partial posterior median dorsal plates; Asterolepis ? amulensis Lyarskaja, 1981, based on one anterior ventrolateral plate), there is an inability to address how variation within these species (due to ontogenetic stage or otherwise) may overlap with that of the type species or one another.

Upeniece (2011) highlights the dramatic changes in both skeletal dimensions and ornament that ontogeny imposes on a growth series of $A$. ornata specimens from the Lode Formation of Latvia (variously dated as Givetian or Frasnian). Among $A$. ornata anterior median dorsal plates, the cranial margin width to midline length index ranges between $c .24$ in juveniles and $c .8$ in large adults (Upeniece 2011: fig. 4.21). This range includes all but one of the indices that Wells (1964) uses to distinguish among nine different species of Asterolepis. Upeniece (2011) also identifies a progression of ontogenetic changes in skeletal ornament from smooth to finely-meshed to reticular in juveniles to tubercular and conjoined tubercular (ridged) in adults. The variation in ornament within $A$. ornata alone, then, includes all of the ornament types reported for the group Asterolepis. In one reported case (LDM 260/359, Upeniece 2011: fig. 4.39C), finely-meshed, reticular, and tuberculate ornaments are all present on a single anterior median dorsal plate.

A revision of Asterolepis alpha-taxonomy is beyond the scope of the present work so the fourteen species listed above serve as the comparative context for the descriptive work presented here. In most cases, the new material is compared against the type species. Most of the asterolepidoid fossils from NV2K17 were found isolated and unassociated and this poses its own taxonomic challenge. For one example, of the twenty-five isolated nuchal plates from the site, we use size category and ornament to assign only one to the new species and the rest to Asterolepidoidei sp. indet.

The recent series of paleontological expeditions to Nunavut (1999-2014) have made significant contributions to the fauna of the Fram Formation. The NV2K17 locality alone has produced a diverse assemblage of vertebrate taxa since its discovery in 2000. In addition to the antiarchs described here, the fauna includes an undescribed dipnoan, two holoptychiid porolepiforms (Laccognathus embryi Downs, Daeschler, Jenkins \& Shubin, 2011 [Downs et al. 2011a] and Holoptychius bergmanni Downs, Daeschler, Jenkins \& Shubin, 2013 [Downs et al. 2013]), a tristichopterid (Eusthenopteron jenkinsi Downs, Daeschler, Long \& Shubin, 2018 [Downs et al. 2018]), at least two undescribed osteolepidids, and the elpistostegalian Tiktaalik roseae (Daeschler et al. 2006; Shubin et al. 2006; Downs et al. 2008). The present work strengthens the similarity between the Middle/Late Devonian faunas from the Fram Formation (Frasnian) of Arctic Canada, the Escuminac (Frasnian) Formation of Quebec, and the Gauja/Lode (Givetian/Frasnian), Amata (Givetian), Daugava (Frasnian), and Ogre (Frasnian) Formations of the Baltic States (Esin et al. 2000). All of these faunas include at least one species of antiarch, holoptychiid

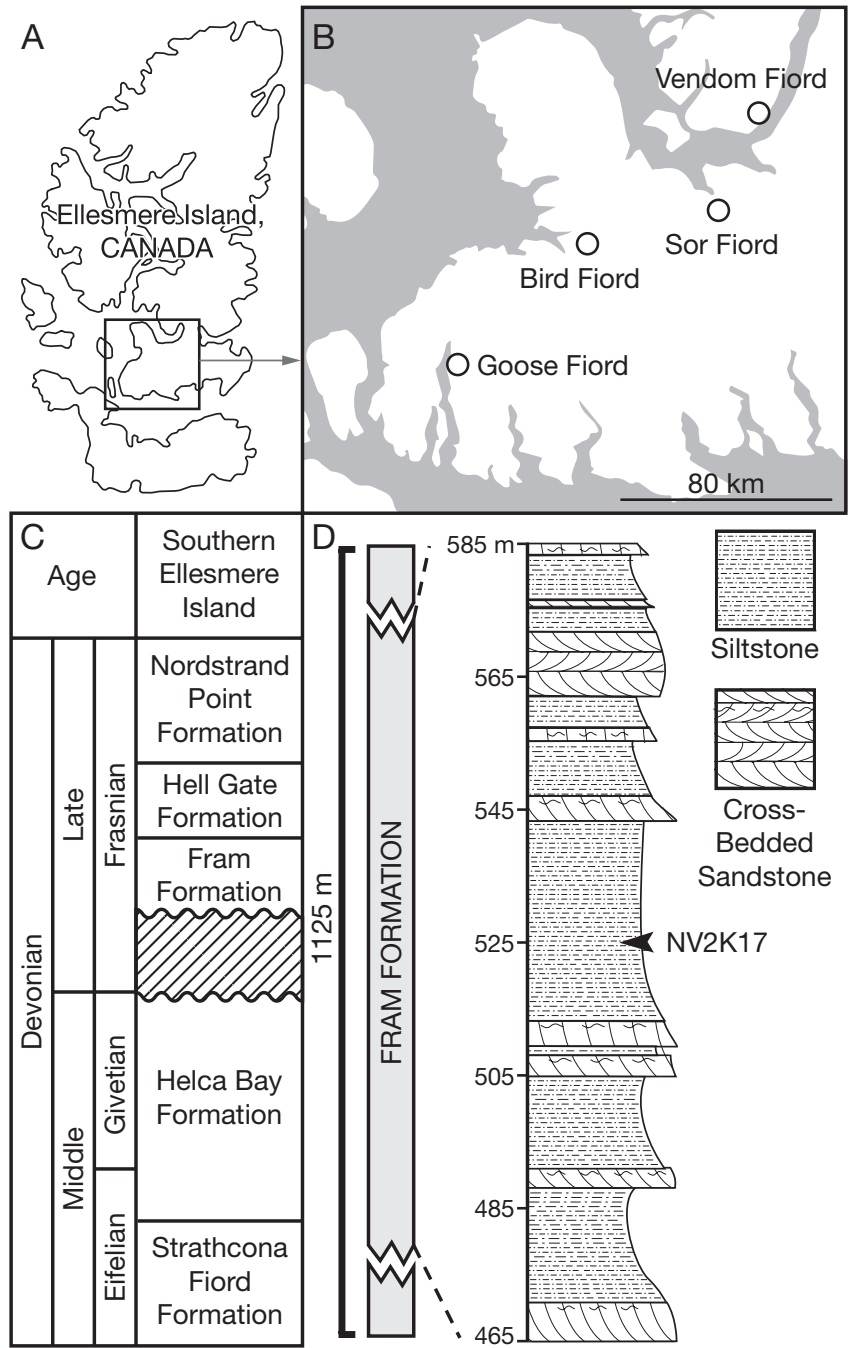

FIG. 1. - A, Map of Ellesmere Island; B, map of southwestern Ellesmere Island (rectangular inset of A) showing the locations of the field sites that have produced antiarch material; C, stratigraphy of the Okse Bay Group; D, stratigraphy of the Fram Formation type section.

porolepiforms, at least one species of tristichopterid tetrapodomorph, and an elpistostegalian tetrapodomorph (Esin et al. 2000; Downs et al. 2011a).

\section{GEOLOGICAL SETTING}

The Franklinian wedge is the oldest of three successions that comprise the Phanerozoic sedimentary rocks of the Canadian Archipelago. It transitions from Cambrian carbonate shelf and evaporite deposits at its base to terrestrial fluvial clastics in the Upper Devonian (Mayr, 1994). On southern Ellesmere Island, the Franklinian wedge is represented by the five Middle-Upper Devonian formations of the Okse Bay Group. The Okse Bay Group is the product of sediment erosion into a foreland basin from three sources: the Ellesmerian Orogenic Belt to the north and the Caledonian Orogenic Belt and Precambrian Shield, both to the east (Embry 1988). Scotese \& McKerrow (1990) provide a paleogeographic reconstruction that places the Ellesmerian Orogenic Belt in an equatorial position in Northern Euramerica (Laurussia). 
The (Frasnian) Fram Formation of Ellesmere Island is the middle of the five formations in the Okse Bay Group (Fig. 1C). From lower to upper, these five are Strathcona Fiord (Eifelian), Hecla Bay (Eifelian-Givetian), Fram (Frasnian), Hell Gate (Frasnian), and Nordstrand Point (Frasnian) (Embry \& Klovan 1976). The Fram Formation is a series of ten to twentymeter-thick, fining-upward sequences of alternating siltstones and resistant, cliff-forming sandstones with erosive bottoms (Embry \& Klovan 1976; Embry 1991). The siltstones constitute most of the depth of each sequence. Embry \& Klovan (1976) interpreted the Fram Formation type section as meandering stream channel and point bar deposits (sandstones) and overbank floodplain deposits (siltstones).

We report on two species of Asterolepis from the NV2K17 locality, within the type section of the Fram Formation (Fig. 1D), in the southward dipping limb of the Schei Syncline near the east arm of Bird Fiord on southern Ellesmere Island. Palynological data date the Fram Formation to the Late Devonian (early-middle Frasnian; Chi \& Hills 1976; Embry \& Klovan 1976). The productive zone of the NV2K17 locality is approximately 20 centimeters thick. In this zone, vertebrate fossils appear as isolated skeletal elements or as incomplete skeletons in partial articulation. There is no evidence for size sorting or preferred orientation. With this taphonomic context, Miller et al. (2007) interpreted the site as the result of a single channel avulsion event during which vertebrate remains were deposited on the floodplain and quickly buried with suspended load.

$\begin{array}{ll}\text { INSTITUTIONAL ABBREVIATIONS } \\ \text { C.U. } & \text { Paleontological Collections, Cornell University, Ithaca, } \\ & \text { New York; } \\ \text { LDM } & \text { Latvian Museum of Natural History, Riga, Latvia; } \\ \text { NUFV } & \text { Nunavut Fossil Vertebrate Collection, Canadian } \\ & \begin{array}{l}\text { Museum of Nature, Ottawa, Ontario; } \\ \text { PIN }\end{array} \\ & \begin{array}{l}\text { Paleontological Institute of the Russian Academy of } \\ \text { Sciences, Moscow; }\end{array} \\ \text { PMO } & \text { Natural History Museum, University of Oslo, Oslo. }\end{array}$

\section{SYSTEMATIC PALEONTOLOGY}

ANTIARCHI Cope, 1885

ASTEROLEPIDOIDEI Miles, 1968

Family AsTEROLEPIDAE Traquair, 1888

Genus Asterolepis Eichwald, 1840 sensu Agassiz (1844)

TYPE SPECIES. - Asterolepis ornata Eichwald, 1840 (Eichwald 1840b), sensu Agassiz (1844); East Baltic area, Main Devonian Field, Gauja Formation, Middle Devonian (late Givetian).

\section{REMARKS}

Eichwald first proposed the name Asterolepis ornata in a November, 1839, letter to H. G. Bronn of Stuttgart. The letter was published sometime after April of the following year (Eichwald 1840b) in the annual journal at which Bronn served as co-editor, Neues Jahrbuch für Mineralogie, Geognosie, Geologie und Petrekaften-Kunde. This reference has been mis- cited (e.g., Lyarskaja 1981; Upeniece 2011) as a publication of Neues Jahrbuch für Mineralogie, Geognosie, Geologie und Paläontologie, a title change for the journal that only occurred after Bronn's death in 1862 and then continued through to 1942. In an earlier 1840 publication (published in April), Eichwald (1840a: 79) mentions, though misspells, "Astrolepis" but makes no formal proposal of the name and does not use the name of the type species, $A$. ornata. His casual use of the name "Astrolepis" here is likely due to his previously written, though not yet published, proposal of $A$. ornata in his letter to Bronn. The quirk of publication schedules means that the earlier Eichwald (1840a) publication, in Bulletin scientifique de l'Académie impériale des Sciences de Saint Petersbourg, is the first published occurrence of "Astrolepis," though not of the type species name. This understanding reveals that the original spelling of Asterolepis is actually "Astrolepis." However, considering the subsequent spelling's prevailing (though not exclusive; see Murphy et al. 1976) usage and its common attribution to the publication containing the original spelling (e.g., Traquair 1888; Woodward 1891; Rohon 1899; Gross 1931, 1933; Karatajūte-Talimaa 1963; Lyarskaja 1981; Janvier \& Villarroel 2000; Moloshnikov 2008; Newman \& Den Blaauwen 2018), the International Code of Zoological Nomenclature (Article 33.3.1) supports Asterolepis as a correct spelling.

Asterolepis alticristata n. sp.

urn:Isid:zoobank.org:act:D6EAF712-9D00-4A37-9612-93CF17333564

Asterolepis sp. - Daeschler et al. 2006: 759.

“Large asterolepidid" - Downs et al. 2011a: 994.

“Asterolepid placoderm" - Downs et al. 2013: 48.

“Asterolepid antiarch" - Downs et al. 2018: 1.

HolOTYPE. - NUFV 897, anterior median dorsal plate of thoracic skeleton (Fig. 2).

ETymology. - From the Latin 'altus,' high, and 'crista,' crest, in reference to the tall midline crest of the anterior median dorsal plate that helps to diagnose the species.

TYPE LOCALITY AND HORIZON. - NV2K17 locality ( $77^{\circ} 09^{\prime} 59.1^{\prime}$ "N, $86^{\circ} 16^{\prime} 9.42$ "W), Fram Formation near the eastern arm of Bird Fiord on southern Ellesmere Island, Nunavut Territory, Canada. Palynological data indicate an early Frasnian age (medius and maclarenii zones of Chi \& Hills 1976).

ReFERRED MATERIAL. - NUFV 1265, nuchal plate; NUFV 812, 813, premedian plates; NUFV 822, partial anterior median dorsal plate; NUFV $814,815,823,828,834,835,842,845,849-851$, $854,856,860-861,864,867,870-873,876-878,884-886,889$, $890,896,1270-1277$, crests of anterior median dorsal plates; NUFV $796,806,874,879,898$, posterior median dorsal plates; NUFV 802.1, 802.2, 821, 848, posterior median dorsal fragments; NUFV 892, articulated partial thoracic and pectoral skeleton including median ventral, right and left anterior dorsolateral plates, anterior ventrolateral plates, dorsal central 1 and ventral central 1 plates; NUFV 895, right mixilateral plate. 

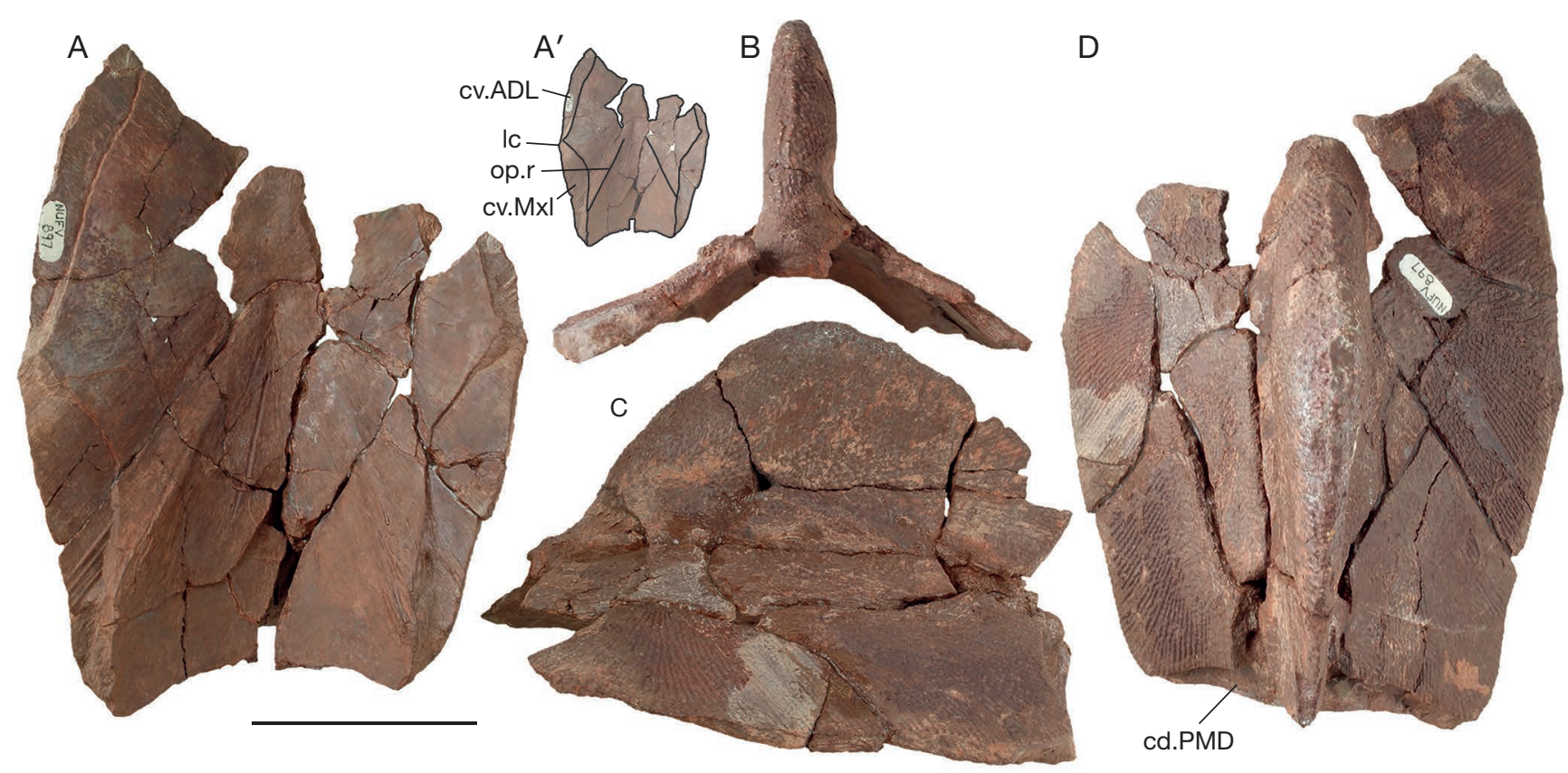

FIG. 2. - Asterolepis alticristata n. sp., NUFV 897, holotype, anterior median dorsal plate in visceral (A, photograph; A', labeled illustration), cranial (B), left lateral (C), and dermal (D) views. Abbreviations: cd.PMD, area overlapped by the posterior median dorsal plate; $\mathbf{c v . A D L}$, area overlapping the anterior dorsolateral plate; cv.Mxl, area overlapping the mixilateral plate; Ic, lateral corner; op.r oblique posterolateral ridge. Scale bar: $5 \mathrm{~cm}$.

DiAgNOSIS. - Antiarch referred to Asterolepis by the presence of an anterior median dorsal plate that broadly overlaps the mixilateral plates (Moloshnikov 2008). Distinguished from previously described species by the following combination of anatomical features: 1) a tall, rounded midline crest that rises from a position near the tergal angle of the anterior median dorsal plate and loses most of its height before reaching the posterior median dorsal plate and (2) a midline crest of the posterior median dorsal plate that decreases in height cranial to caudal.

\section{REMARKS}

Because the new species is diagnosed by a crest of the anterior and posterior median dorsal plates, we use spatial association with diagnostic plates or plate fragments to refer additional material to the species (including isolated premedian, mixilateral and nuchal plates and an articulated partial skeleton [NUFV 892] that lacks the median dorsal plates). All of these referred materials also share a size category and dermal ornament with the Asterolepis alticristata n. sp. type specimen.

\section{DESCRIPTION OF CEPHALIC SKELETON}

Nuchal plate (Fig. 3A-C)

The nuchal plate (NUFV 1265: Fig. 3A-C) is short and wide; the width/length index (maximum transverse width $\times 100$ divided by maximum sagittal length) is 195 . The maximum reported index for Asterolepis is 210 in Asterolepis scabra (Young 1987). Several smaller, unassignable nuchals from NV2K17 (NUFV 1247, 1248, 1252, 1254, 1263) have an index that is comparable with, though none higher than, this reported maximum (See Description of Other Asterolepidoid Specimens from NV2K17). As in Asterolepis ornata, the width across the lateral corners is slightly greater than the width across the caudolateral corners; this is despite the presence of pronounced caudolateral processes. As is true of all known species of Asterolepis, the notch for the postpineal plate is shallow, reaching no further caudal than the lateral corners of the nuchal plate. The central pit-line groove (Fig. 3A' $[\mathrm{cp} 1]$ ) extends across the width of the nuchal; it exhibits a pronounced median dip and meets the lateral margins of the plate well caudal to the lateral corners. Tiny, parasagittal foramina just caudal to the pit-line are weakly visible among the tubercles of the ornament. Stensiö (1931) presumed these to be the external openings of the endolympatic ducts (Fig. 3A'[d.end]).

The nuchal is a thick plate with broad and deep zones of overlap onto lateral (Fig. 3A' [cv.L]) and paranuchal (Fig. 3A' [cv. $\mathrm{Pn}])$ plates. There is a very short obtected area (Fig. 3A' $[\mathrm{nm}]$ ) along the nuchal's caudal margin that is unornamented though not depressed. The caudal margin of the plate is notched in parasagittal positions close to the plate's midline. These notches border a short caudal midline process (Fig. 3A'[ml.p]) of the plate similar to the one described in A. ornata (Upeniece 2011).

The visceral surface of the nuchal exhibits a supraotic thickening (Fig. 3B'[sot]) that surrounds the large supraoccipital pits (containing the internal openings of the endolymphatic ducts; Stensiö 1931; Fig. 3B'[sop]). The caudal surface of the nuchal plate exhibits a median occipital crista (Fig. 3C [mo.c]) and, on either side of it, parasagittal fossae that were interpreted by Stensiö (1931) to be attachment areas for cranial levator muscles. In caudal view, the visceral surface of the plate has a tight, nearly semicircular arch to it. The areas lateral to the visceral arch are depressed relative to the area external to it such that a pronounced horizontal ledge runs across the plate at the most external reach of the visceral arch. The caudal surface of the nuchal is the thickest part of the plate and there is a dramatic decrease in nuchal 

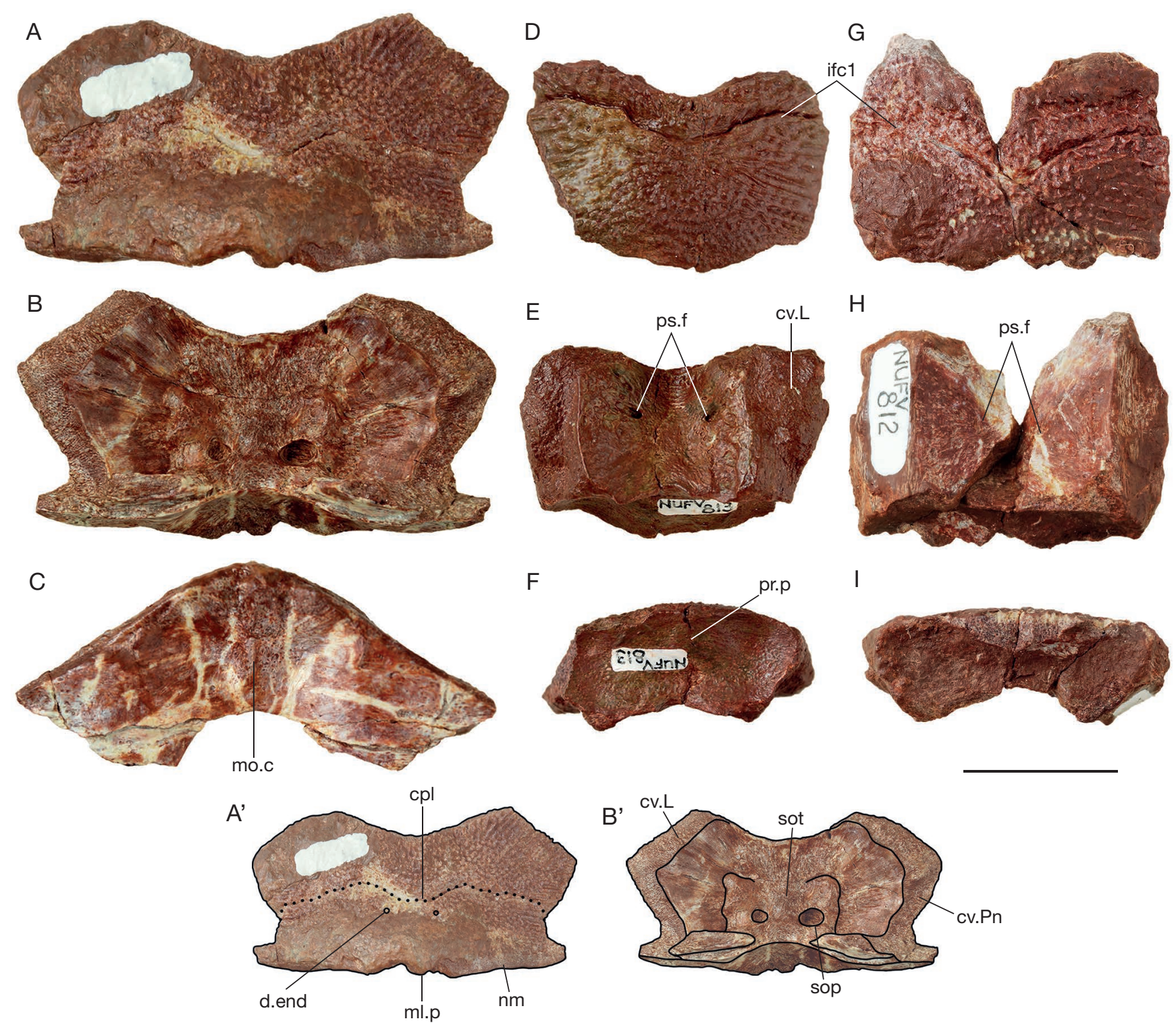

FIG. 3. - Asterolepis alticristata n. sp.: A-C, NUFV 1265, nuchal plate in dermal (A, photograph; A', labeled illustration), visceral (B, photograph; B', labeled illustration), and caudal (C) views; D-F, NUFV 813, premedian plate in dermal (D), visceral (E), and caudal (F) views; G-I, NUFV 812, premedian plate in dermal (G), visceral (H), and caudal (I) views. Abbreviations: cpl, central pit-line line groove; cv.L, area overlapping the lateral plate; cv.Pn, area overlapping the paranuchal plate; d.end, endolymphatic duct; ifc1, principal section of infraorbital pit-line groove; ml.p, midline process; mo.c, median occipital crista; nm, obtected area; pr.p, prerostral process; ps.f, parasagittal foramina; sop, supraoccipital pit; sot, supraotic thickening. Scale bar: $2 \mathrm{~cm}$.

thickness rostrally from the depressed visceral extensions of the plate's caudal surface.

The ornament of the nuchal plate is coarsely tuberculate. Tubercles are fused into ridges close to the rostral and lateral margins of the plate; these ridges radiate from the center.

\section{Premedian plate (Fig. 3D-I)}

The two premedian plate specimens referred to Asterolepis alticristata n. sp. (NUFV 812 [maximum sagittal length of $29.85 \mathrm{~mm}$ ] and 813 [same length $=22.02 \mathrm{~mm}$ ]: Fig. 3D-I) share a size category and an ornament type but differ from one another in some specific details. The premedian plate has been recognized as a source of intraspecific variation throughout Antiarchi (Young 1984; Downs et al. 2011b).
Both specimens exhibit the generalized premedian plate shape that has been well described in Asterolepis ornata (Lukševičs 2001). Both are thick plates, especially at the caudal end, and are arched across the midline. Both have unornamented zones in lateral positions along the depressed rostral margin of the plate; the rostral margin exhibits a midline notch. In both, the tall caudal surface is depressed rostrally (analogue of the bothriolepidid preorbital recess; Lukševičs 2001) and this surface has a prerostral process (Fig. 3F[pr.p]) across the midline with a small depression on the midline (the nasal notch of Lukševičs 2001). The prerostral process separates the orbital cavities. Both premedian specimens are widest at the lateral corners and these corners are closer to the rostral margin than they are to the caudal one. 


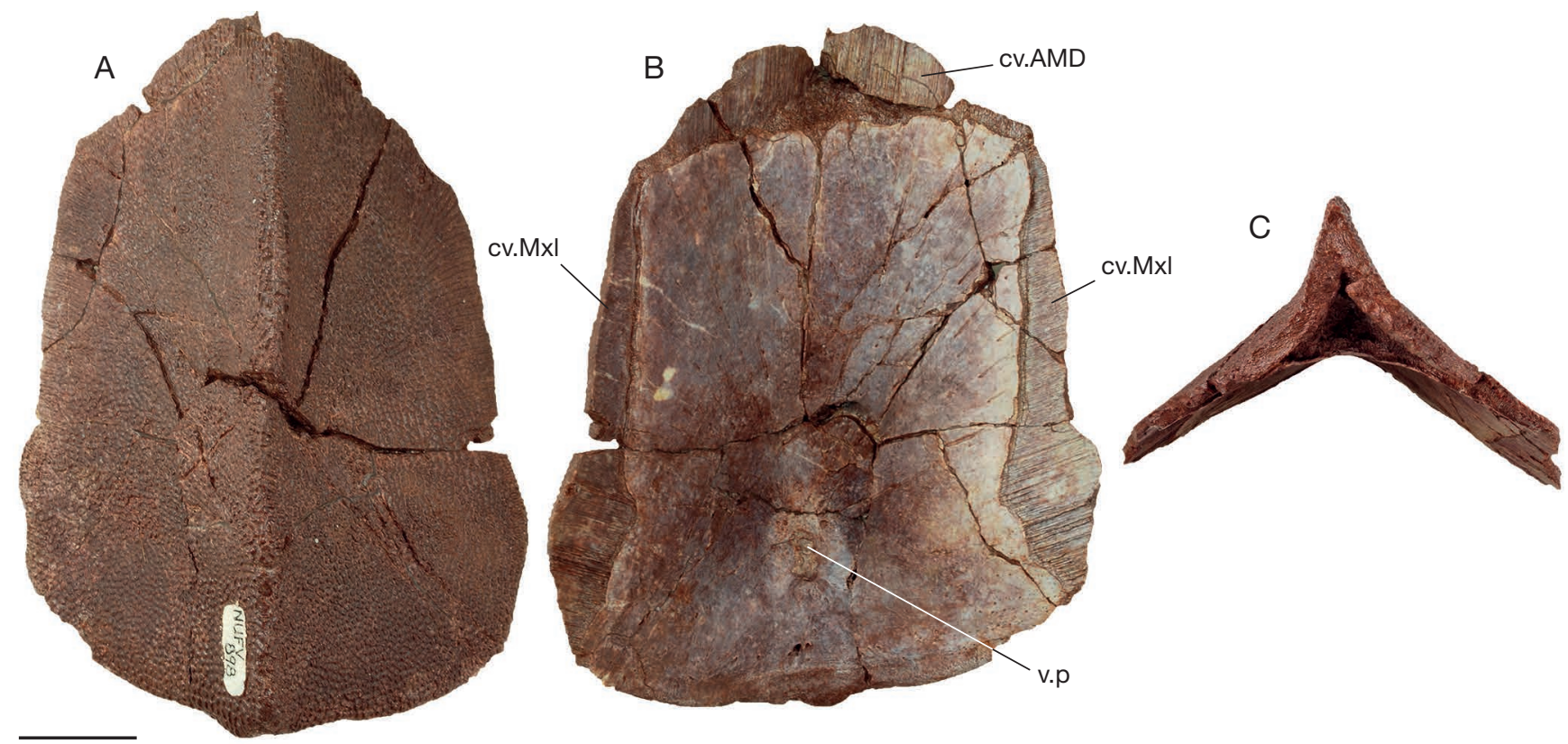

FIG. 4. - Asterolepis alticristata n. sp., NUFV 898, posterior median dorsal plate in dermal (A), visceral (B), and cranial (C) views. Abbreviations: cv.AMD, area overlapping the anterior median dorsal plate; cv.Mxl, area overlapping the mixilateral plate; v.p, visceral pit. Scale bar: $2 \mathrm{~cm}$.

The two premedian specimens referred to A. alticristata n. sp. have a width/length index (as calculated for the nuchal above) of 134 (NUFV 812) and 157 (NUFV 813). These values are within the range of variation that Upeniece (2011) reported for adult Asterolepis ornata (120-233). This broad range of values for adult $A$. ornata again highlights the variability of this plate within a single antiarch species.

The principal section of the infraorbital pit-line groove (Fig. 3D[ifc1], G[ifc1]) extends across the width of the premedian but follows a different path on each of the two specimens. In NUFV 812 (Fig. 3G), the groove forms a caudally directed point at the midline and strongly arches rostrally on either side of the midline. It is positioned at about mid-length along the plate, such that the midline dip of the groove reaches into the caudal half of the plate. In contrast, the groove on NUFV 813 (Fig. 3D) has a shallow, rounded dip at the midline and is much straighter across its entire width. The groove is situated close to the rostral margin of the premedian such that no part of it reaches into the plate's caudal half.

Tiny foramina (Fig. 3E[ps.f], H[ps.f]) penetrate the visceral surface of the premedian; the two most prominent are parasagittally located in the rostral half of the plate. The external ornament of the premedian is similar to that of adult Asterolepis ornata in that rows of tubercles radiate out from the center of ossification. Close to the lateral margins of the plate, the tubercles within a row fuse together to form ridges.

\section{DESCRIPTION OF THORACIC AND PECTORAL SKELETONS Anterior median dorsal plate (Fig. 2)}

The anterior median dorsal plate of Asterolepis alticristata n. sp. features a tall rounded crest on the midline. The remarkable height (c. $60 \mathrm{~mm}$ in the largest specimen, NUFV 897, maximum anterior median dorsal plate width $=112.55 \mathrm{~mm}$ ) and thickness (c. $18 \mathrm{~mm}$ in NUFV 897) of the crest is unlike any previously described for Asterolepis (Fig. 2). The crest rises sharply from a position just cranial to the tergal angle and reaches its maximum height just caudal to the center of the anterior median dorsal plate, nearly in line with the plate's greatest width. The long dorsal margin of the crest caudal to the maximum height is slightly convex to deeply concave. The closest point of comparison among antiarchs, for a crest in this position and of this height, is in Bothriolepis cristata Traquair, 1895 (Scotland). A tall dorsal crest also appears in Bothriolepis gippslandiensis Hills, 1929 (Victoria, Australia); Bothriolepis cullodenensis Long, 1983 (Victoria Australia); and Bothriolepis zadonica Moloshnikov, 2004 (Central European Russia). In each of these three examples, however, the crest is formed nearly equally by anterior median dorsal and posterior median dorsal plates; the crest rises from near the anterior median dorsal plate's tergal angle and reaches its maximum height only at the contact between anterior median dorsal and posterior median dorsal plates (Moloshnikov 2004). In addition to the three partial anterior median dorsal plates with crests (NUFV 822, 896, 897 [holotype]), the $A$. alticristata n. sp. referred material includes thirty-seven isolated crests from anterior median dorsal plates. No other part of the $A$. alticristata n. sp. anatomy is better represented in the sample. The size and shape variation among these crests does not fit a single growth trend (See Discussion: Variation in anterior median dorsal plate crests of Asterolepis alticristata n. sp.).

At the caudal end of the anterior median dorsal plate, the midline crest continues onto the posterior median dorsal plate. In NUFV 897 (maximum crest height c. $60 \mathrm{~mm}$ ), the height of the anterior median dorsal plate crest at its caudal terminus is $c .14 \mathrm{~mm}$. The total length of the anterior median dorsal plate crest on NUFV 897, from where 
it first rises to its contact with the crest of the posterior median dorsal plate is $108.10 \mathrm{~mm}$. The anterior median dorsal plate of $A$. alticristata n. sp. is steeply vaulted in the transverse plane such that the dorsal surfaces lateral to the crest face distinctly craniolaterally. The posterior median dorsal plate overlaps an unornamented, depressed zone along the caudal end of the anterior median dorsal plate's dorsal surface (Fig. 4D[cd.PMD]). None of the available material allows description of the anterior median dorsal plate cranial to the crest. In NUFV 897, the tergal angle is cranial to the lateral corners (Fig. $2 \mathrm{~A}^{\prime}[\mathrm{lc}]$ ) of the anterior median dorsal plate and caudal to the most cranial position of the midline crest.

The visceral surface of the anterior median dorsal plate shows the depressed surfaces where the plate overlaps the anterior dorsolateral (Fig. 2A' $[\mathrm{cv} . \mathrm{ADL}]$ ) and mixilateral (Fig. 2A'[cv.Mxl]) plates cranial and caudal to the anterior median dorsal lateral corners. On each side, these overlap surfaces are continuous with one another across the lateral corner. Obliquely oriented, low, wide ridges (oblique posterolateral ridge of Karatajūte-Talimaa 1963; Fig. 4A'[op.r]) extend and widen from the center of the anterior median dorsal plate's visceral surface to the mixilateral underlap close to the caudolateral corners of the plate.

The ornament of the dorsolateral faces of the anterior median dorsal plate is densely tuberculate centrally and ridged closer to the lateral and caudal margins of the plate. The ridges retain the appearance of fused tubercles and radiate from the center. The ornament of the crest is densely tuberculate especially at the base. The tubercles are disorganized at the base, continuing the ornament type of the plate's dorsolateral surfaces, and are organized into rows more distally. In one specimen (NUFV 872), these organized tubercles are fused into high ridges. The rows of tubercles or ridges radiate from a cranioproximal position on the crest.

\section{Posterior median dorsal plate (Fig. 4)}

The posterior median dorsal plate of Asterolepis alticristata $\mathrm{n}$. sp. is elongate and narrow. The greatest width of the plate is across the lateral corners; these corners are located close to the caudal margin of the plate. There is little increase in width from craniolateral to caudolateral corners and much of that increase occurs abruptly just cranial to the caudolateral corner. With nearly parallel lateral margins and craniolateral margins that angle toward the midline, the posterior median dorsal plate of $A$. alticristata n. sp. is more obelisk-shaped in dorsal view than the bulging diamond-shaped posterior median dorsal plate of Asterolepis ornata (Lyarskaja 1981: pl. 30, figs 1, 3). As is typical for Asterolepis, the posterior median dorsal plate broadly overlaps both anterior median dorsal (Fig. 4B [cv.AMD]) and mixilateral (Fig. 4B [cv.Mxl]) plates with the deepest zones of overlap at the rostral midline (onto the posterior median dorsal plate) and in the positions of the caudolateral corners (onto the mixilateral plates).

A low midline crest extends along the entire length of the plate that shallows from its cranial to its caudal end. There is a sharp division between the narrow peak of the posterior median dorsal plate's external tissue layers and the more shallow vaulting of the plate's visceral surface. Between the two there is a mass of bone tissue that fills the vaulted core of the peak (Fig. 4C). The division between external and internal tissue layers results in a dramatic thickening of the plate along the midline, from the peak of the midline crest to the smooth visceral surface. The non-overlapping portion of the visceral surface (Fig. 4B) is generally rectangular but for a broadening at its caudal end. On the visceral midline, near the caudal end, there is a small circular pit (Fig. 4B[v.p]) that is surrounded by parasagittal depressions cranial to it and a single midline depression caudal to it.

The ornament is densely tuberculate. The tubercles are tightly-spaced and arranged into rows in locations close to the plate's margin; these rows are parallel to the plate's lateral edges in a small specimen (NUFV 796) and perpendicular to the cranial and lateral margins in large specimens (NUFV 874, 898; Fig. 4). In positions along the lateral margin of the largest known posterior median dorsal plate (NUFV 898; Fig. 4), the tubercles are fused together to form ridges.

\section{Anterior dorsolateral plate (Fig. 5)}

The anterior dorsolateral plate of Asterolepis alticristata n. sp. expectedly overlaps the mixilateral plate (Fig. 5A' $[\mathrm{cv}$. $\mathrm{Mxl}]$ ) and is overlapped by the anterior median dorsal plate (Fig. 5B' [cd.AMD]). The dorsolateral ridge (Fig. 5B'[dlr]) separates the dorsal lamina (maximum transverse width of $47.60 \mathrm{~mm}$ in NUFV 892 [left side]) from the lateral lamina (maximum transverse height of $38.69 \mathrm{~mm}$ in NUFV 892 [left side]). The angle between dorsal and lateral laminae is impossible to measure in NUFV 892 due to preservational flattening of the specimen that has deformed those laminae into nearly the same plane. The thickest part of the plate is in the position of the processus obstans (Fig. 5C'[pr.o]) which consists of a short, medial, cranially-pointing process and a cranially-facing facet that likely accommodated the postmarginal plate of the cephalic skeleton. The ornament is densely tuberculate with those tubercles close to the dorsolateral ridge, on both dorsal and lateral laminae, appearing in rows parallel to that linear feature. Along the ventral margin of the lateral lamina, tubercles are conjoined into ridges oriented perpendicular to the contact between anterior median dorsal and anterior ventrolateral plates. The main lateral line groove (Fig. $5 C^{\prime}[\mathrm{lcg}]$ ) is on the lateral lamina of the anterior dorsolateral plate and follows a path that is roughly parallel with the dorsolateral ridge (Fig. 5C'[dlr]).

\section{Anterior ventrolateral plate (Fig. 5)}

The anterior ventrolateral plate forms a broad thick platform for the submarginal plates of the Asterolepis cephalic skeleton. Along with the anterior dorsolateral plate, the cranial end of the anterior ventrolateral plate's lateral lamina forms a wide, crested backwall for the cephalic skeleton. One specimen (NUFV 892; Fig. 5) preserves the lateral lamina, pectoral articulation, and only a short section of the ventral lamina of both anterior ventrolateral plates of Asterolepis alticristata n. sp. As in adult Asterolepis ornata, the lateral lamina of the 

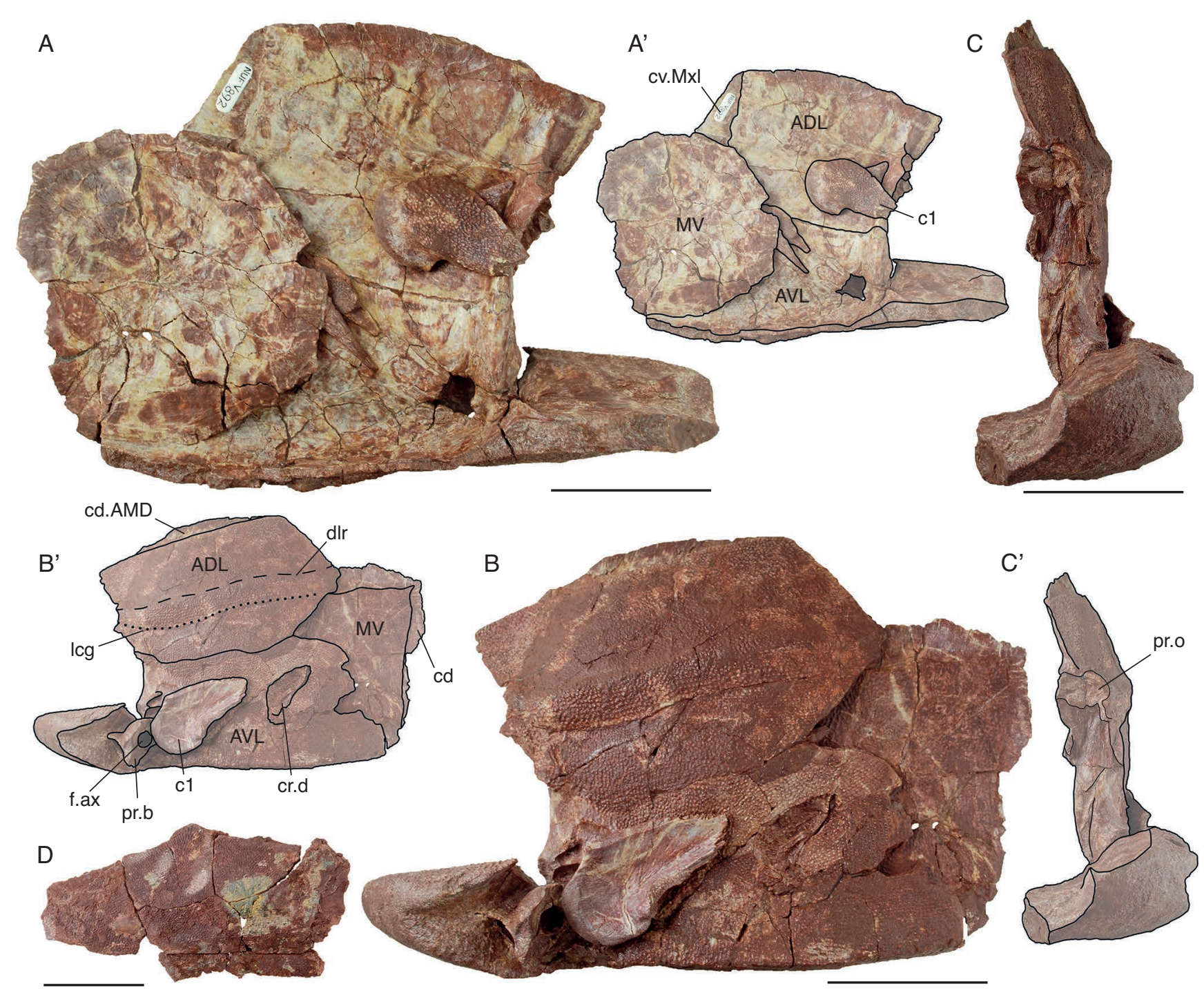

FIG. 5. - Asterolepis alticristata n. sp.: A-C, NUFV 892, left side of articulated partial thoracic skeleton in visceral (A, photograph; $\mathbf{A}^{\prime}$, labeled illustration), left lateral (B, photograph; B', labeled illustration), and cranial (C, photograph; C', labeled illustration) views; D, NUFV 895, right mixilateral plate in dermal view. Abbreviations: ADL, anterior dorsolateral plate; AVL, anterior ventrolateral; c1, central 1 plate; $\mathbf{c d}$, area overlapped by ventral thoracic plates; cd.AMD, area overlapped by the anterior median dorsal plate; cr.d, crescent-shaped depression; cv.Mxl, area overlapping the mixilateral plate; dlr, dorsolateral ridge; f.ax, foramen axillaris; Icg, main lateral line groove; MV, median ventral plate; pr.b, processus brachialis; pr.o, processus obstans. Scale bar: $5 \mathrm{~cm}$.

anterior ventrolateral plate is tall across its entire length and reaches its maximum height close to the caudal end. The anterior ventrolateral plate is remarkably thick at the pectoral articulation and, at $38.87 \mathrm{~mm}$ in NUFV 892, presents the position of greatest skeletal thickness known for the species. The processus brachialis (Fig. 5B'[pr.b]) resides in a fossa that is deeply excavated from the ornamented surface. This fossa narrows to a point cranially. The processus brachialis is penetrated by an oval-shaped (long axis dorsal-ventral) foramen axillaris (Fig. 5B' [f.ax]). The most cranial margin of the plate's ventral platform exhibits a tall concave, cranial-facing facet that likely accommodated the semilunar plate. As in A. ornata, this facet terminates laterally in a cranial-pointing process (the antero-mesial process of Upeniece 2011); further lateral is the most cranial point of the plate (the anterior lateral corner of Upeniece 2011).
The ornament of the anterior ventrolateral plate's lateral lamina is densely tuberculate; the tubercles are arranged in rows that radiate from a position just caudal to the pectoral articulation. The preserved portion of the ventral lamina, just ventral to the pectoral articulation, is unornamented as is a depressed zone just dorsal to the fossa that surrounds the processus brachialis.

Note. On the lateral lamina of the left anterior ventrolateral plate of NUFV 892, there is a crescent-shaped depression (Fig. 5B' [cr.d]) that interrupts the surrounding ornament pattern. The ornament within the depression consists of larger, isolated and fused tubercles that are more widely spaced and chaotically-organized than those of the surrounding lateral lamina. This depression may represent bone repair of puncturetype damage or an instance of skeletal pathology. 
TABLE 1. - Antiarch-producing sites within the Fram Formation on southern Ellesmere Island, Nunavut Territory, Canada.

\begin{tabular}{|c|c|c|}
\hline $\begin{array}{l}\text { Site } \\
\text { Designation }\end{array}$ & Coordinates & $\begin{array}{l}\text { Stratigraphic } \\
\text { Position }\end{array}$ \\
\hline NV0207 & $77^{\circ} 39^{\prime} 8.34^{\prime \prime} \mathrm{N}, 83^{\circ} 24^{\prime} 18.9^{\prime \prime} \mathrm{W}$ & lower-most Fram Fm \\
\hline & 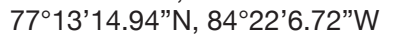 & upper Fram Fm \\
\hline NV0203 & $77^{\circ} 11^{\prime} 32.05^{\prime \prime N}, 84^{\circ} 19^{\prime} 17.28^{\prime \prime} \mathrm{W}$ & middle Fram Fm \\
\hline NV0205 & $77^{\circ} 10^{\prime} 19.02^{\prime \prime N}, 84^{\circ} 16^{\prime} 14.1^{\prime \prime} \mathrm{W}$ & lower Fram Fm \\
\hline NV0403 & $77^{\circ} 10^{\prime} 35.82^{\prime \prime} \mathrm{N}, 86^{\circ} 16^{\prime} 47.7^{\prime \prime} \mathrm{W}$ & lower-most Fram Fm \\
\hline NV0404 & $77^{\circ} 10^{\prime} 41.64^{\prime \prime} \mathrm{N}, 86^{\circ} 15^{\prime} 42.96 ” \mathrm{~W}$ & lower Fram Fm \\
\hline NV2K16 & $77^{\circ} 9^{\prime} 54.42 " N, 86^{\circ} 8^{\prime} 5.94^{\prime \prime W}$ & middle Fram Fm \\
\hline NV0802 & $77^{\circ} 10^{\prime} 36.24^{\prime \prime} \mathrm{N}, 86^{\circ} 14^{\prime} 54.6^{\prime \prime} \mathrm{W}$ & lower-most Fram Fm \\
\hline NV2K17 & $77^{\circ} 9^{\prime} 53.7^{\prime \prime} \mathrm{N}, 86^{\circ} 16^{\prime} 9.42^{\prime \prime} \mathrm{W}$ & middle Fram Fm \\
\hline NV0402 & $77^{\circ} 10^{\prime} 8.34^{\prime \prime} \mathrm{N}, 86^{\circ} 10^{\prime} 58.26^{\prime \prime} \mathrm{W}$ & middle Fram Fm \\
\hline NV2K15 & $77^{\circ} 9^{\prime} 37.14^{\prime \prime} \mathrm{N}, 86^{\circ} 9^{\prime} 7.74^{\prime \prime} \mathrm{W}$ & upper Fram Fm \\
\hline NV2K01 & $76^{\circ} 45^{\prime} 39.06^{\prime \prime N}, 88^{\circ} 28^{\prime} 33.42^{\prime \prime} \mathrm{W}$ & middle Fram Fm \\
\hline NV2K02 & $76^{\circ} 45^{\prime} 42^{\prime \prime} \mathrm{N}, 88^{\circ} 28^{\prime} 32.58^{\prime \prime} \mathrm{W}$ & middle Fram Fm \\
\hline NV2K03 & $76^{\circ} 45^{\prime} 50.7^{\prime \prime N}, 88^{\circ} 28^{\prime} 26.94^{\prime \prime} \mathrm{W}$ & middle Fram Fm \\
\hline NV2K05 & $76^{\circ} 45^{\prime} 53.1^{\prime \prime} \mathrm{N}, 88^{\circ} 28^{\prime} 24.18^{\prime \prime} \mathrm{W}$ & middle Fram Fm \\
\hline NV2K07 & $76^{\circ} 45^{\prime} 36.54^{\prime \prime} \mathrm{N}, 88^{\circ} 28^{\prime} 43.14^{\prime \prime} \mathrm{W}$ & middle Fram Fm \\
\hline
\end{tabular}

\section{Median ventral plate (Fig. 5A, B)}

The one median ventral plate (NUFV 892; Fig. 5A, B) is best preserved in visceral view. The outline of the median ventral plate is generally circular although it appears to pinch to form blunt points in at least three corners. What is exposed of the external surface (Fig. 5B) shows a densely tuberculate ornament with evidence for rows of fused tubercles in some areas. The median ventral plate is overlapped by anterior ventral lateral and posterior ventral lateral plates. Two such overlap surfaces are continuous with one another and visible on the dermal surface of the median ventral plate of NUFV 892. It is impossible to determine which plates overlap these visible surfaces because the plate is out of articulation in NUFV 892.

\section{Mixilateral plate (Fig. 5D)}

Only one specimen (NUFV 895; Fig. 5D) is complete enough to both recognize it as a mixilateral plate and assign it to Asterolepis alticristata n. sp. NUFV 895 is incomplete and lacks most of the zones of overlap that accommodate the anterior median dorsal and posterior median dorsal plates. But for a short segment, the specimen also lacks the plate's lateral lamina. The ornament is densely tuberculate with the tubercles arranged in rows close to cranial and caudomedial edges. These rows of tubercles meet each of these two ornamented margins at steeply oblique angles. On the visceral surface, oblique ridges extend caudolaterally from the caudal end of the mixilateral's contact with the anterior median dorsal plate. These continue the path of the ridges on the visceral surface of the anterior median dorsal plate that are described above.

\section{Posterior ventrolateral plate}

Several fragments (NUFV 802.1, 802.2, 821, 848) are identifiable as the caudoventral corner of the posterior ventrolateral plates and are here attributed to Asterolepis alticristata n. sp. They are not complete enough to support an anatomical description but for the ornament pattern of rows of isolated or conjoined tubercles that is consistent with much of the rest of the known skeleton.
Pectoral appendage (Fig. 5A, B)

The identifiable plates of the Asterolepis alticristata n. sp. pectoral appendage include dorsal and ventral central 1 plates (Fig. $5 \mathrm{~A}[\mathrm{c1}], \mathrm{B}[\mathrm{c} 1]$ ) and a lateral marginal 2 plate, but the material also includes additional unidentified central and marginal plates. The dorsal and ventral central 1 and lateral marginal 2 plates appear as they do in the type species. On the central plates, the ornament is tuberculate with larger, more widely spaced tubercles at the proximal end. On the marginal plate, the ornament is densely tuberculate with no obvious pattern to their arrangement.

\section{Asterolepis cf. radiata Rohon, 1899}

Asterolepis cf. radiata Rohon, 1899: 8.

Asterolepissp. - Daeschler et al. 2006: 759. — Downs et al. 2011a: 994.

"Asterolepid placoderm" - Downs et al. 2013: 48.

"Asterolepid antiarch" - Downs et al. 2018: 1.

LOCALITY AND HORIZON. - NV2K17 locality (77 $09^{\prime} 59.1^{\prime \prime} \mathrm{N}$, $\left.86^{\circ} 16^{\prime} 9.42^{\prime \prime} \mathrm{W}\right)$, Fram Formation near the eastern arm of Bird Fiord on southern Ellesmere Island, Nunavut Territory, Canada. Palynological data indicate an early Frasnian age (medius and maclarenii zones of Chi \& Hills 1976).

DIAGNOSIS. - Antiarch referred to Asterolepis by the presence of an anterior median dorsal plate that broadly overlaps the mixilateral plates (Moloshnikov 2008). Referred to Asterolepis cf. radiata by the presence of an external skeletal ornament that is composed entirely of rows of tubercles and/or ridges that radiate from the center of ossification to the margins of the plate (Rohon 1899).

REFERRED MATERIAL. - NUFV 795, 797-800, 804, anterior median dorsal plate; NUFV 809, 825, posterior median dorsal plate; NUFV 846, 863, mixilateral plate; NUFV 883, partial anterior dorsolateral and mixilateral plates.

\section{DESCRIPTION OF THORACIC AND PECTORAL SKELETONS Anterior median dorsal plate (Fig. 6A, B)}

The five complete anterior median dorsal plates of Asterolepis cf. radiata (NUFV 795, 797-800) exhibit a size and shape range consistent with known material of $A$. radiata. Among these five specimens, the midline length of the plate is between $79.75 \mathrm{~mm}$ (NUFV 798) and $94.94 \mathrm{~mm}$ (NUFV 800 ) and width across the lateral corners (Fig. $6 \mathrm{~A}[\mathrm{lc}]$ ) is between $54.41 \mathrm{~mm}$ (NUFV 798) and $68.09 \mathrm{~mm}$ (NUFV 800). The width/length index of the plate (width across the lateral corners $\times 100 /$ midline length), then, is between 65 and 73 for the five specimens. The lateral corners of these plates are positioned close to the midpoint of the plate's length. This presents a differently shaped anterior median dorsal plate than that of those Asterolepis species with anterior median dorsal plate lateral corners near the plate's caudal end (Asterolepis essica Lyarskaja, 1981, Asterolepis estonica Gross, 1940, Asterolepis säve-söderberghi Stensïo \& Säve-Söderbergh, 1938, and Asterolepis syasiensis Lyarskaja, 1981). The tergal angle (Fig. 6A[ta]) is cranial to the center of the anterior median dorsal plate in this new sample of 
Asterolepis cf. radiata, and as previously reported for the species, a low dorsal midline crest extends from the tergal angle to the caudal end of the plate. The cranial end of the plate is blunt (width of cranial margin $\times 100 /$ midline length $=$ 13.58 in largest specimen, NUFV 800) and therefore unlike the narrow pointed cranial tip of the anterior median dorsal plate in Asterolepis chadwicki (same index reported as 6.00 in C.U. No. 42344, Wells 1964).

The anterior median dorsal plate of Asterolepis cf. radiata is vaulted in the transverse plane and vaulted but less so in the sagittal plane. A steeply depressed zone at the caudal end of the anterior median dorsal plate's external surface accommodates the overlap of the posterior median dorsal plate (Fig. 6A[cd. PMD]). This overlap zone is crested like the ornamented surface but the crest here is accordingly depressed below the ornamented one. The visceral surface of the anterior median dorsal plate shows the steeply depressed areas of anterior dorsolateral plate (Fig. 6B' [cv.ADL]) and mixilateral plate (Fig. 6B' [cv.Mxl]) underlap. These are connected to one another across the lateral corners. Low, wide, oblique ridges (Fig. 6B' [op.r]) of the visceral surface extend from the area opposite to the tergal angle to the caudolateral corners of the plate. The cranial end of the plate's visceral surface exhibits a rough area (Fig. 6B' $[$ r.a]) on the midline that has been interpreted as an attachment site for cranial levator muscles in Asterolepis (Moloshnikov 2008).

The external ornament of all five anterior median dorsal plates attributed here to Asterolepis cf. radiata consists of rows of isolated or conjoined tubercles that radiate from the tergal angle out to the margins of the ornamented surface. This ornament is consistent with Rohon's (translated from 1899: 23) original description of $A$. radiata ("tubercles arranged in radial lines or of radiating or parallel bars"), but is unlike the dramatically ridged/grooved ornamented surface of PIN No. 3725/1191, an anterior median dorsal plate attributed to $A$. radiata by Moloshnikov (2008).

\section{Posterior median dorsal plate (Fig. 6C, D)}

The posterior median dorsal plate of Asterolepis cf. radiata (NUFV 809, 811, 825; Fig. 6C, D) is known from two incomplete specimens that permit a limited description. The plate is strongly vaulted in the transverse plane with a sharp midline angle that extends along the entire preserved length of the external surface (Fig. 6C); this angle does not form a raised crest like the caudal end of the anterior median dorsal plate. As is expected for Asterolepis, the posterior median dorsal plate overlaps onto both anterior median dorsal (Fig. 6A[cd.PMD]) and mixilateral (Fig. 6D'[cv.Mxl]) plates. The area overlapping the mixilateral plate is widest at a position in the plate's caudal half and tapers both cranially and caudally along the posterior median dorsal plate's lateral margin. Oblique caudolateral margins form a pointed caudal terminus to the plate but the posterior median dorsal plate does not exhibit either a caudal median process as in Asterolepis maxima (Traquair 1914) and juvenile Asterolepis ornata (Upeniece \& Upenieks 1992; Upeniece 2011) nor a caudal median notch as in Asterolepis essica (Lyarskaja 1981) and large adult individuals of $A$. ornata (Upeniece 2011). The visceral surface exhibits two parasagittal depressions (Fig. 6D'[ps.d]) that align nearly with the widest portion of the area overlapping the mixilateral plate. Just caudal to these, on the midline, is a large circular pit (Fig. 6D' [v.p]). The ornament is formed of low, rounded tubercles that are organized into linear rows; these radiate from a midline position near the caudal margin of the plate.

\section{Mixilateral plate (Fig. 6E)}

The mixilateral plate in this sample of Asterolepis cf. radiata is represented by two nearly complete specimens (NUFV 846, 863; Fig. 6E). Wide overlap zones on the external surface of these mixilaterals accommodate the anterior dorsolateral, anterior median dorsal, and posterior median dorsal plates (Fig. 6E[cd.ADL, cd.AMD, cd.PMD]). The external ornament of the dorsal lamina comprises rows of conjoined tubercles radiating from a caudolateral position. The lateral lamina is very short (maximum height is 0.25 times maximum width of the dorsal lamina) and carries a unique slotted, interlocking contact with the posterior ventrolateral plate not seen along the other margins of thoracic plates. The ornament of the lateral lamina is conjoined tubercles that appear to radiate from the same point as those of the dorsal lamina. The dorsolateral ridge of the mixilateral plate forms a low, sharp crest.

\section{DESCRIPTION OF OTHER ASTEROLEPIDOID SPECIMENS FROM NV2K17}

With one noted exception (NUFV 831, articulated cephalic skeleton; Fig. 7A, B), the specimens described here were collected as isolated plates at the NV2K17 field locality (Fram Formation, early Frasnian) on Ellesmere Island. We assign NUFV 852 (mixilateral plate; Fig. 7N) to Asterolepis sp. indet., NUFV 808 (lateral plate; Fig. 7M) to cf. Asterolepidoidei, and the other described specimens to Asterolepidoidei sp. indet. for the reasons explained below. NV2K17 is a locality with at least two species of Asterolepis so much or all of the material described in this section is likely to belong to one or the other of the species presented above. In addition to the described material, there are antiarch plates from NV2K17, including anterior dorsolateral, anterior ventrolateral, posterior ventrolateral, median ventral, and pectoral appendage plates, that do not present the anatomical details necessary to support a meaningful description or a more specific taxonomic assignment than Antiarchi indet.

The discovery of a Bothriolepis sp. indet. anterior median dorsal plate (NUFV 847) at NV2K17, and bothriolepidid material from stratigraphically analogous localities, urges taxonomic caution when considering indeterminate antiarch material from the site. Although Asterolepis is, overwhelmingly, the best represented antiarch group at NV2K17, the presence of Bothriolepis at the locality convinces us to not simply attribute all of this locality's antiarch material to Asterolepis or even Asterolepidoidei. In the Discussion section of this paper, we report on antiarch material from throughout the Fram Formation, including NUFV 847 and asterolepidoid material from other localities. 
NUFV 831: Partial cephalic skeleton (Fig. 7A, B)

NUFV 831 (Fig. 7A, B) includes nuchal, postpineal, partial left paranuchal, partial left lateral, right paranuchal, and partial right lateral plates. The specimen is attributed to Asterolepidoidei sp. indet. according to the presence of a wide postpineal that sutures with the lateral plates and separates the nuchal plate from the orbital opening (Moloshnikov 2008).

This partial cephalic skeleton is strongly vaulted in the transverse (visceral surface of nuchal appears as a tight semi-circular arch in caudal view) and sagittal planes. The otic-occipital depression is deeply developed on the visceral surface of nuchal, paranuchal, lateral, and postpineal plates. The narrow unornamented dorsal-facing obstantic margin of the nuchal wraps around and deepens to form the caudalfacing margin of the paranuchals. The central pit-line groove (Fig. 7A' [cp1]) is separated into left and right parts; each part weakly arches rostrally and crosses the other at the midline. The grooves meet the nuchal's margin in a position well caudal to the lateral corners. The ornament is almost entirely anastomosing or linear ridges that radiate from a nearly central position of each plate present. The only isolated tubercles present are caudal to the central pit-line groove on nuchal and paranuchal plates and immediately lateral to the orbital opening on the lateral plate.

\section{Premedian plates (Fig. 7C-F)}

Five small premedian plates from NV2K17 (NUFV 817, 833, 857: Fig. 7C, D; NUFV 1266, 1267: Fig. 7E, F) are impossible to refer to either of the two species described above but all may be referred to Asterolepidoidei sp. indet. according to the presence of a medial notch in the rostral margin (Moloshnikov 2008). Among these five is morphological variation that does not scale against size (plate width). This may result from multiple species represented in the sample or from the high level of variability in the antiarch premedian (Young 1984; Downs et al. 2011b). Of the four more completely preserved specimens, the smaller two (NUFV 1266 and 1267) are relatively short and wide (width/length index = 154 in NUFV 1267) relative to the larger two (NUFV 833 [same index $=111]$ and $857[=116]$ ).

Two types of external ornament are present in the sample, one predominantly ridged with ridges radiating from the center of the plate and tubercles, when present, clustered centrally along the rostral and caudal margins (NUFV 817, 857; Fig. 7C, D; 1266), and the other predominantly tuberculate with short radiating ridges along the lateral margins (NUFV 833, 1267; Fig. 7E, F). One of these ornament types is no more likely than the other at a given premedian size.

In these unreferred specimens, the principal section of the infraorbital pit-line groove follows the two different paths described above for Asterolepis alticristata n. sp. One path is close to the rostral margin and follows the contour of that margin but for a median caudal dip. The other exhibits the median dip but is straighter across its length and is located in the middle of the premedian plate. As with the ornament types, a premedian of a given size is no more likely to show one path than the other.
Nuchal plates (Fig. 7G-L)

We refer 24 nuchals from NV2K17 (NUFV 819, 829, 880 [Fig. 7G-I]; 1120, 1121, 1247-1251, 1252 [Fig. 7J-L]; 12531264, 1269) to Asterolepidoidei sp. indet. according to the lack of an orbital margin. These nuchals (with widths between $24.32 \mathrm{~mm}$ in NUFV 1260 and $39.26 \mathrm{~mm}$ in NUFV 1258) belong to a different size category than that of Asterolepis alticristata n. sp. (nuchal width of 62.42 in the one referred specimen, NUFV 1265). There is no consistent relationship between width/length index of the nuchal (whether length is measured as midline length or maximum sagittal length) and nuchal size (width) thus suggesting against the entire sample representing a single growth series. However, the top eight values of the index using maximum sagittal length (from 176 in NUFV 819 to 202 in NUFV 1248) are among the top ten widest nuchals in the sample. In other words, the widest nuchals also tend to be relatively short. The variation in this index for these twenty-four nuchals includes the value calculated for A. alticristata n. sp. (195 in NUFV 1265). Vaulting of the nuchal in the transverse plane is differently developed across the sample; some are tightly arching, others are flatter. This too is inconsistent relative to size of the nuchal plate.

In this sample of nuchals, the middle pit-line groove exhibits variation in its path. In all cases, it extends across the width of the nuchal and arches rostrally on left and right sides. In some specimens, the groove is separated into left and right components that cross one another at the midline (e.g., NUFV 880; Fig. 7G-I). In others, there is one unbroken middle pit-line groove that dips caudally at the midline (e.g., NUFV 1252; Fig. 7J-L). There is also variation in where the groove meets the lateral margin of the plate, from a rostral position close to the nuchal's lateral corners (e.g., NUFV 880; Fig. 7G-I) to a caudal position just rostral to the caudolateral corners (e.g., NUFV 1252; Fig. 7J-L). These sources of variation do not trend with width of the nuchal plate.

Ornament is variable in this sample of nuchals. Whenever ornament is observable, there are linear ridges close to the rostral and lateral margins of the plate; these ridges present a loosely radial pattern that originates from a caudocentral position. In larger nuchals, centrally, the ornament is tuberculate and these tubercles are either arranged into rows that extend from a caudocentral position to the aforementioned ridges (e.g., NUFV 1252; Fig. 7J-L) or the tubercles do not exhibit any discernible organization (e.g., NUFV 1249). In smaller nuchals, more of the ornamented surface is ridged, often having the appearance of fused tubercles, and these ridges radiate from a caudocentral position to the rostral and lateral margins (e.g., NUFV 880; Fig. 7G-I). When tubercles are present in the smaller nuchals, they are in line with these ridges.

\section{NUFV 808: Lateral plate (Fig. 7M)}

A single, incomplete lateral plate (NUFV 808; Fig. 7M) lacks the caudal end but preserves the thick orbital margin and contact surface for the premedian plate. The depth of the medial margin and the dermal ornament of the plate are consistent with the lateral plate of NUFV 831, the partial cephalic skeleton (described above) that is diagnosable as asterolepidoid. We refer NUFV 808 to cf. Asterolepidoidei sp. indet. due to 


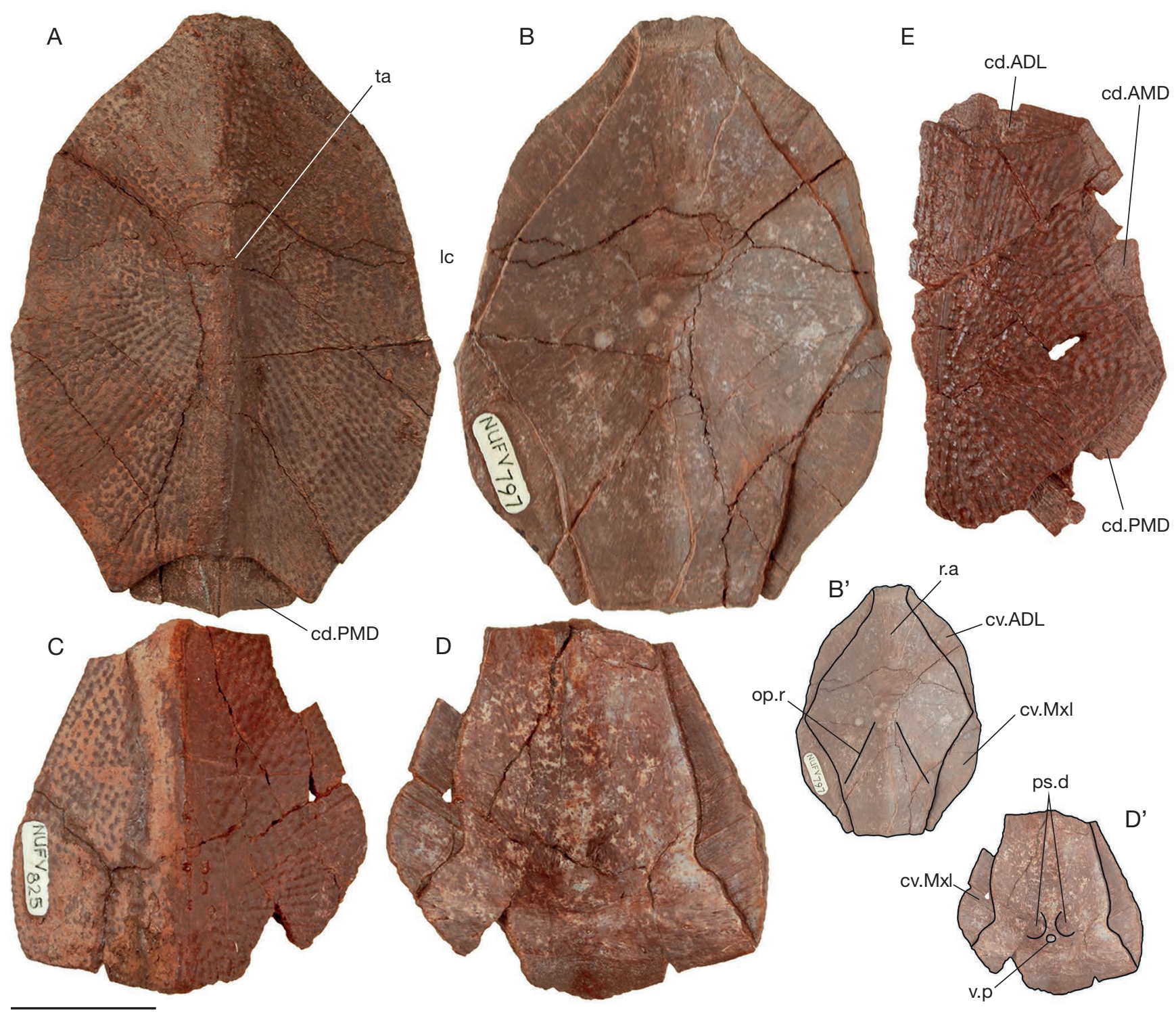

FIG. 6. - Asterolepis cf. radiata: A, B, NUFV 797, anterior median dorsal plate in dermal (A) and visceral (B, photograph; B', labeled illustration) views; C, D, NUFV 825, partial posterior median dorsal plate in dermal (C) and visceral (D, photograph; D', labeled illustration) views; E, NUFV 863, mixilateral in dermal view. Abbreviations: cd.ADL, area overlapped by the anterior dorsolateral plate; cd.AMD, area overlapped by the anterior median dorsal plate; cd.PMD, area overlapped by the posterior median dorsal plate; cv.ADL, area overlapping the anterior dorsolateral plate; cv.MxI, area overlapping the mixilateral plate; Ic, lateral corner; op.r, oblique posterolateral ridge; ps.d, parasagittal depressions; r.a, rough area; ta, tergal angle; v.p, visceral pit. Scale bar: $2 \mathrm{~cm}$.

a lack of diagnostic features on this incomplete, isolated plate. The preserved length of NUFV 808 is $46.86 \mathrm{~mm}$; the plate is thickest $(14.81 \mathrm{~mm})$ at the rostral end of the orbital margin. The rostral margin of the plate is unornamented and depressed below the ornamented surface. The path of the infraorbital pitline (Fig. $7 \mathrm{M}[\mathrm{ifc1}]$ ) interrupts the ornament of the plate's rostral end. The visceral surface of NUFV 808 is smooth and does not preserve the lateral's contribution to the otic-occipital depression. The external ornament is different than that on the lateral plate included in NUFV 831. In NUFV 808, the ornament is entirely tuberculate. Fine tubercles are tightly clustered lateral to the orbital opening and larger tubercles, some conjoined, are organized into linear or curving rows between orbital margin and pit-line. Rostral to the pit-line, similarly large tubercles, some conjoined, do not exhibit any specific organization.

\section{NUFV 852: Mixilateral plate (Fig. 7N)}

NUFV 852 (Fig. 7N) is a mixilateral plate in a much smaller size category than that of Asterolepis alticristata n. sp. Its assignment to cf. Asterolepis sp. indet. is supported by a wide area of overlap by the anterior median dorsal plate (Moloshnikov 2008). The anterior median dorsal plate of Grossolepis also overlaps the mixilateral plate; we assign NUFV 852 to cf. Asterolepis sp. indet. according to the pronounced width of the overlap zone. The dorsal lamina ornament is densely tuberculate with no apparent organization to the tubercles; this is a close match to the mixilateral ornament in $A$. alticristata $\mathrm{n}$. sp. The lateral lamina is only partially preserved so height is impossible to measure. Ornament of the preserved portion of the lateral lamina appears similar to that of the dorsal lamina. 


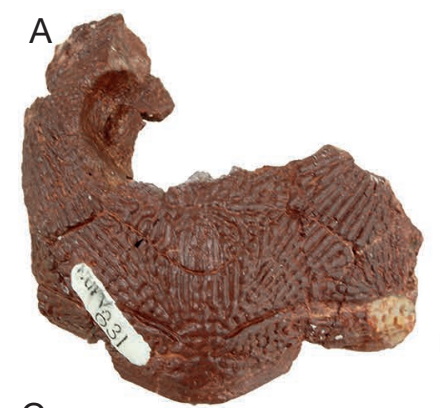

C
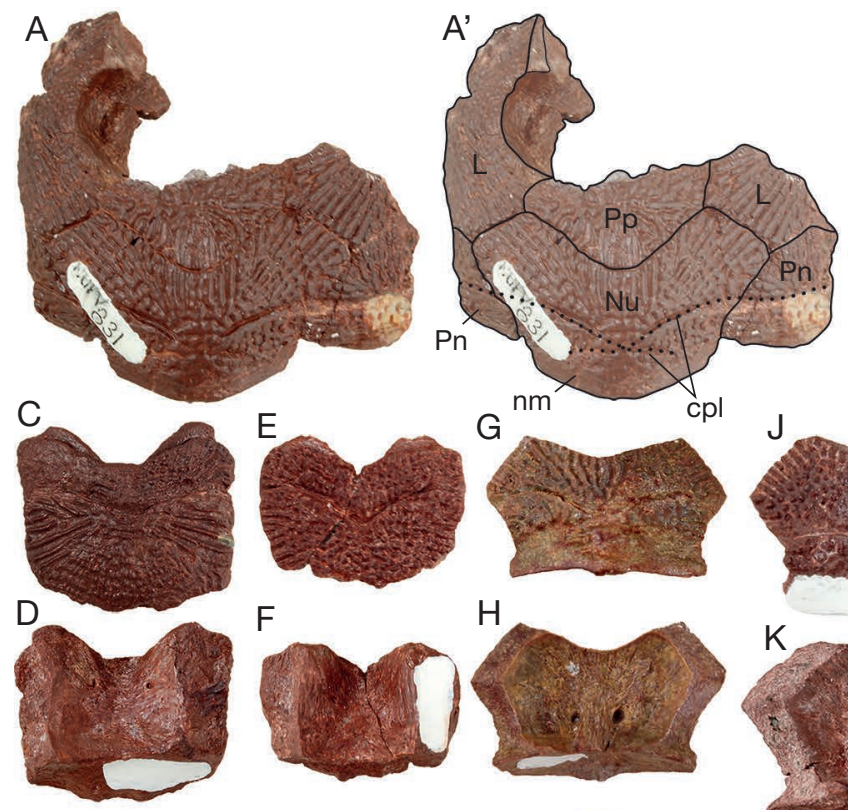

G
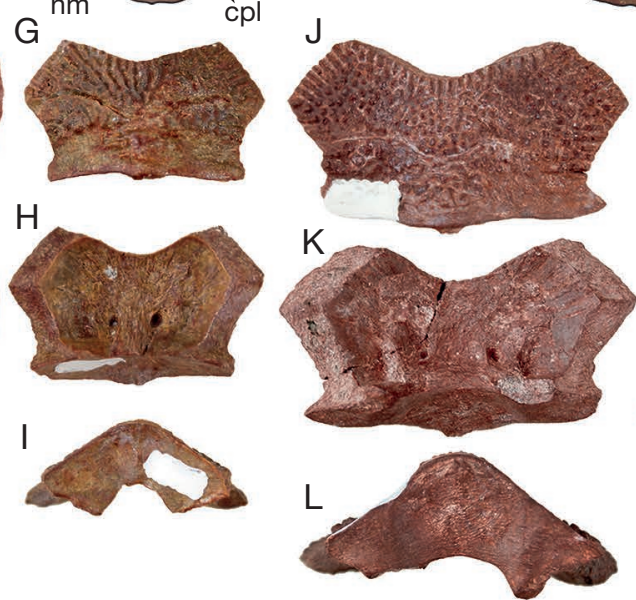

$\mathrm{B}^{\prime}$
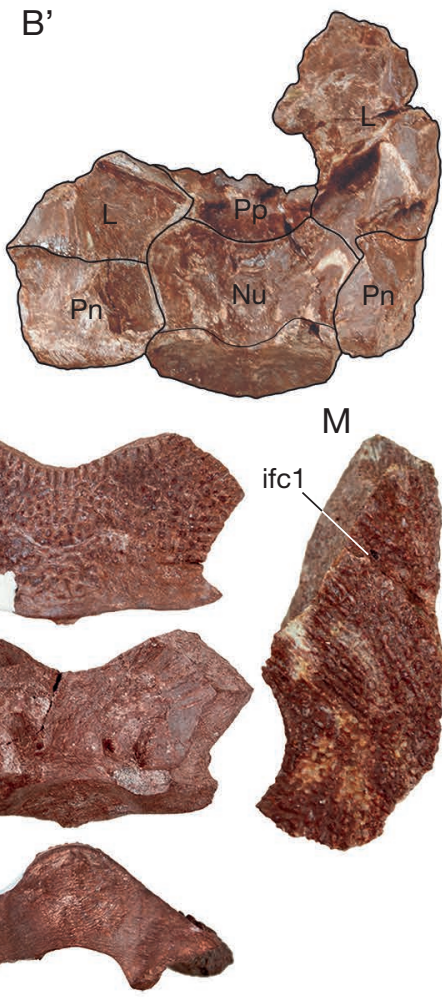

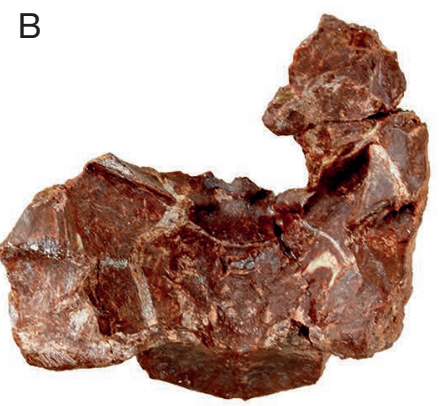

N

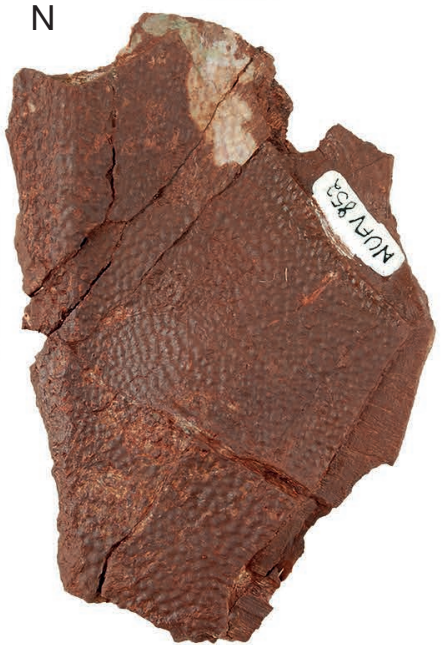

FIG. 7. - A-M, Asterolepidoidei sp. indet. from NV2K17, A, B, NUFV 831, articulated partial cephalic skeleton in dermal (A, photograph; A', labeled illustration) and visceral (B, photograph; B', labeled illustration) views; C, D, NUFV 857, premedian plate in dermal (C) and visceral (D) views; E, F, NUFV 1267, premedian plate in dermal (E) and visceral (F) views; G-I, NUFV 880, nuchal plate in dermal (G), visceral (H), and caudal (I) views; J-L, NUFV 1252, nuchal plate in dermal (J), visceral (K), and caudal (L) views; M, NUFV 808, lateral plate in dermal view; $\mathbf{N}$, cf. Asterolepis sp. indet. from NV2K17, NUFV 852, mixilateral plate in dermal view. Abbreviations: $\mathbf{c p l}$, central pit-line line groove; ifc1, principal section of infraorbital pit-line groove; $\mathbf{L}$, lateral plate; $\mathbf{n m}$, obtected area; Nu, nuchal plate; Pn, paranuchal plate; Pp, postpineal plate. Scale bar: $2 \mathrm{~cm}$.

\section{DISCUSSION}

VARIATION IN ANTERIOR MEDIAN DORSAL CRESTS OF ASTEROLEPIS ALTICRISTATA N. SP.

The 37 isolated anterior median dorsal midline crests of the Asterolepis alticristata n. sp. referred material may all be diagnosed to that species on account of their shape (rounded, rises and falls on the anterior median dorsal plate). Despite this taxonomic assignment, it is important to note that variation in the preserved dimensions of these crests do not fit an obvious growth trend. The crests do have a broad size range, whether using height, length, or width as the indication of size. However, the relationship between crest height (measured from visceral surface to distal tip) and maximum width (in the transverse plane) is especially variable with shorter crests (NUFV 849, height = $31.81 \mathrm{~mm}$, maximum width $=13.26 \mathrm{~mm}$ ) sometimes being wider than taller ones (NUFV 877, height $=38.26$, maximum width $=8.80 \mathrm{~mm}$ ). The total length of the crest on the anterior median dorsal plate also does not scale against crest height or width. The shape of the crest, especially in lateral view outline, shows a large degree of variation (Fig. 8).

ANTIARCH OCCURRENCES IN THE FRAM FORMATION The recent series of paleontological expeditions (1999-2014) to the Canadian Arctic has recovered antiarch fossils from throughout the (Givetian/Frasnian) Okse Bay Group. This paper is the first effort to begin to describe those from the Fram Formation. The focus of the descriptions above is the asterolepidoid fossils of the NV2K17 locality, a site that is notable for the completeness and quality of its fossils and the diversity of its vertebrate fauna. In this section, we report on a Bothriolepis sp. indet. anterior median dorsal plate (NUFV 847: Fig. 9C, D) from that locality and on other antiarch fossils from throughout the Fram Formation. All of the Fram Formation localities named in this section are from southern Ellesmere Island (locality coordinates in Table 1) and will be presented in four geographic groups (Vendom Fiord, Sor Fiord, Bird Fiord, and Goose Fiord; Fig. 1B). Within each group, we will try to organize the localities into a generally lower to upper sequence, although precise stratigraphic positions have not been determined for these sites. Except in those cases where a more specific taxonomic assignment is made, all of the specimens presented below are presently regarded as Antiarchi sp. indet. We provide the following brief descriptions of these antiarch fossils in order to present a preliminary inventory of our collecting efforts. Full description, diagnosis, and figuring of these fossils is beyond the scope of the present work.

Low in the Fram Formation, near the mouth of Vendom Fiord, the NV0207 locality has yielded partial antiarch anterior ventrolateral plates (NUFV 1281 [partial plates from multi- 
ple individuals]) in two size categories, a paranuchal (NUFV 1282), partial and complete nuchals (NUFV 1280), a posterior ventrolateral plate fragment (NUFV 1283) and dorsal and/or ventral central 1 plate (NUFV 1284). The nuchals (Fig. 9A) exhibit size variation but otherwise show generally consistent anatomical features. These may be diagnosed as Asterolepidoidei sp. indet. by the lack of orbital margin on the nuchal (Moloshnikov 2008). These nuchals show less arching in the transverse plane than the NV2K17 nuchals described in the previous section. There are protruding caudolateral processes and the caudolateral width of the nuchal is subequal to the width across the lateral corners. The central pit-line groove, but for a midline caudal dip, is very straight and without the rostral arching observed in the nuchal plates from the NV2K17 sample. The nuchal plates of NV0207 have a long, unornamented obtected area that reaches nearly to the pitline groove. The ornament is tuberculate with tubercles that are large, circular or oblong, and few in number. These are usually isolated but are in some places conjoined. The large tubercles show no obvious pattern in their distribution across the external surface. The paranuchal plate (NUFV 1282) may also be diagnosed as Asterolepidoidei sp. indet. because it shares its ornament type with the nuchals and the central pit-line groove on the paranuchal plate aligns with that of similarly-sized nuchals. The groove continues along a straight trajectory across nuchal and paranuchal plates.

Two sites (NV0202, NV0203) from the western side of the drainage up valley from Sor Fiord contain antiarch material. Both of these sites are likely to be higher in the Fram Formation than NV0207 at Vendom Fiord. Material from these sites includes anterior ventrolateral plate fragments (NUFV 1885, 1886).

Locality NV0205 is low in the Fram Formation but likely higher than NV0207. NV0205 has produced a large, lowcrested anterior median dorsal plate (NUFV 1287; Fig. 9B). Thoracic plate fragments at the locality, including posterior ventrolateral plate (NUFV 1288), share size category and ornament with the anterior median dorsal plate and may belong to the same taxon. We assign the low-crested anterior median dorsal plate (NUFV 1287; Fig. 9B) from NV0205 to Asterolepis sp. indet. according to long, narrow dimensions that taper at cranial and caudal ends, and the overlap of this plate onto mixilateral plates (Moloshnikov 2008). This anterior median dorsal plate belongs to a different size category than the low-crested anterior median dorsal plates from NV2K17 that are referred to Asterolepis cf. radiata above. The minimum midline length of the ornamented surface of NUFV 1287 is $151.99 \mathrm{~mm}$ although the actual length is likely longer due to a poorly preserved cranial end of the plate (the corresponding length of the largest anterior median dorsal plate in the Asterolepis cf. radiata sample is $84.51 \mathrm{~mm}$ ). The width of the plate across the lateral corners is $96.86 \mathrm{~mm}$. Specimen condition prevents a measure of cranial margin width or total midline length. The specimen is preserved only in external view; the overlap zone of the posterior median dorsal plate comes to a cranial point at the midline and appears relatively short given the length of the plate. Vaulting of NUFV 1287 in

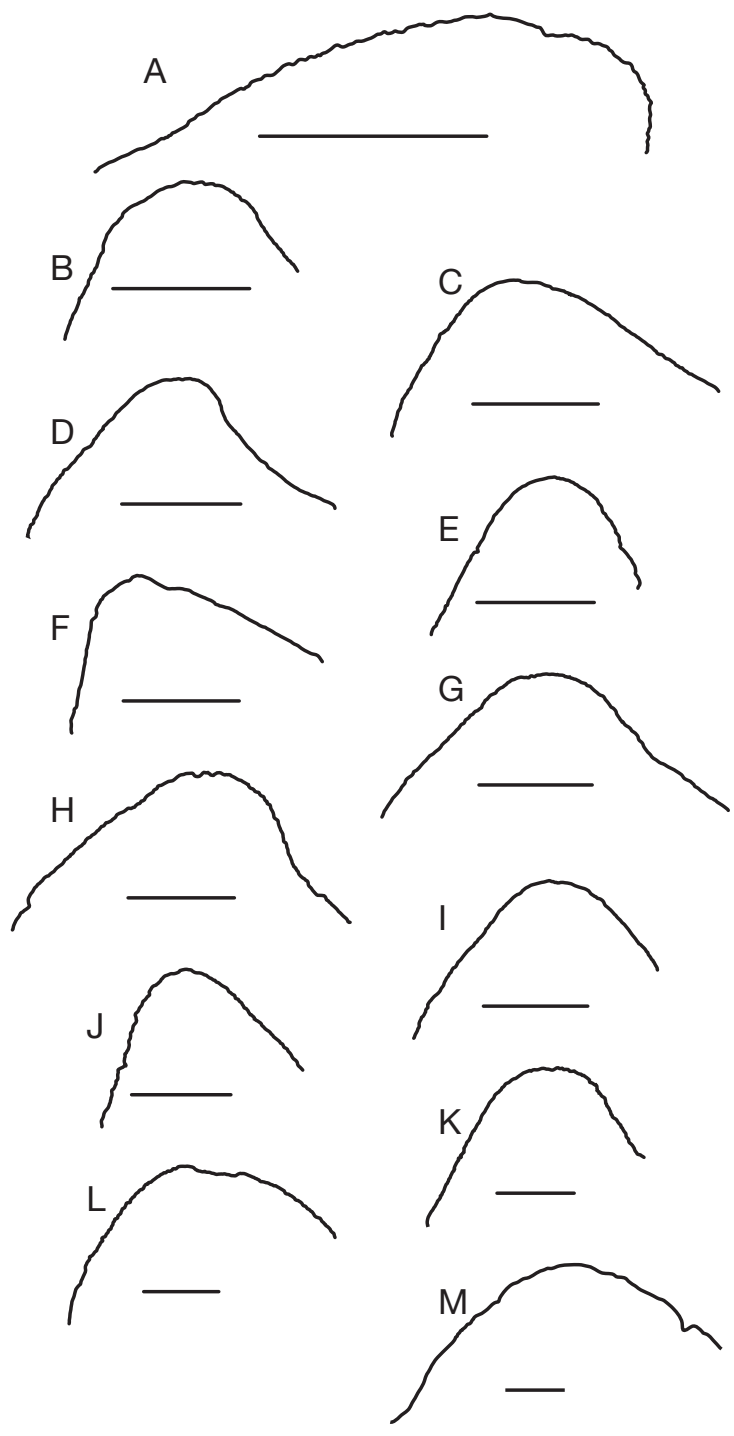

FIG. 8. - Asterolepis alticristata n. sp. outlines of midline crests of anterior median dorsal plates in left lateral view. Each crest is scaled to a common height and ordered according to actual height in order to highlight the shape variation. Each is depicted with the visceral surface as close to horizontal as possible. A, NUFV 1274; B, NUFV 834; C, NUFV 828; D, NUFV 850; E, NUFV 854; F, NUFV 886; G, NUFV 867; H, NUFV 877; I, NUFV 835; J, NUFV 889; K, NUFV 856; L, NUFV 872; M, NUFV 897 (holotype). Scale bars: 2 cm.

transverse and sagittal planes is minor; the midline is slightly raised relative to the margins but, as preserved, the plate is generally flat. A very low crest runs along the midline of the plate, from the tergal angle to the caudal end of at least the ornamented surface. No pit-line is observed on NUFV 1287. The external ornament is quite different than that of both the smaller anterior median dorsal plates in the Asterolepis cf. radiata sample and the corresponding high-crested plates of Asterolepis alticristata n. sp. It is a coarse tuberculate ornament without a radial pattern and without any fusion of tubercles into ridges. Close to the lateral and caudal margins of the ornamented surface, the tubercles are arranged in concentric bands that are parallel to the margin.

Other localities in the same valley as NV2K17, near the east arm of Bird Fiord, preserve antiarch material. NV0403 
and NV0404 may be the lowest of all sites reported here. From NV0403 (just $15 \mathrm{~m}$ above the underlying Hecla Bay Formation), we have recovered plates from one or more large-bodied species of antiarch including pectoral appendage plates and fragments of anterior median dorsal, anterior ventrolateral, and posterior ventrolateral plates (NUFV 1059). From NV0404, there are fragments of dorsal/ventral central 1 plates (NUFV 1289) and a partial posterior median dorsal plate (NUFV 1290). Locality NV2K16 has produced anterior ventrolateral plate fragments (NUFV 1034). From NV0802, there is an anterior ventrolateral plate fragment (NUFV 1291) of a large-bodied antiarch including part of the pectoral appendage articulation.

Among the localities near Bird Fiord is likely the lowest known occurrence of Bothriolepididae in the Fram Formation. In this part of the formation, Bothriolepididae and Asterolepididae are both present and even appear together at the NV2K17 locality. We attribute an anterior median dorsal plate (NUFV 847; Fig. 9C, D) from NV2K17 to Bothriolepis sp. indet. on account of overlap areas that show anterior median dorsal plate broadly overlapping the anterior dorsolateral plate and being overlapped by the posterior median dorsal and mixilateral plates (Young \& Gorter 1981). This well-preserved anterior median dorsal plate is small (length $=42.50 \mathrm{~mm}$ ) and narrow (width/ length index $=76$ ) with a reticulating ornament and strongly developed posterior oblique abdominal pit-line grooves. The visceral surface preserves two median ridges that converge at their rostral ends near the midpoint of the plate. The ridges extend to the caudal margin of the plate. There is an elongate anterior ventral pit in the cranial half of the specimen with postlevator cristae arching obliquely from its cranial end.

In the same valley as NV2K17, a partial cephalic skeleton (NUFV 1292) of Bothriolepididae sp. indet. (diagnosed by a nuchal plate that contributes to the orbital margin, Lukševičs 2001) was collected from NV0402 along with visceral impressions of a partial thoracic skeleton (NUFV 1294) and of a posterior median dorsal plate (NUFV 1293) diagnosed as Bothriolepis sp. indet. on account of its width narrowing caudal to cranial (Stensiö 1948). From NV2K15, a surface-collected microfossil locality up section from NV2K17, we have recovered three partial right lateral plates (NUFV 1296 [Fig. 9E, F]; 1297, 1298), an antiarch premedian plate (NUFV 1295; Fig. 9G, H), six partial nuchal plates (NUFV 1302 [specimen number includes all six]; Fig. 9I, J), posterior median dorsal plate fragments (NUFV 1299), partial anterior ventrolateral plates (NUFV 1300), and a dorsal or ventral central 1 plate of the pectoral appendage (NUFV 1301). The nuchal, lateral, and premedian plates all share a small size, low bone thickness, and reticulating ornament. The contribution of the nuchal plates to the orbital margin supports the assignment of all of these cephalic plates to Bothriolepididae sp. indet. The nuchals are long and narrow. They have a long, unornamented obtected region and central pit-line grooves that cross one another at the midline. Parasagittal openings for the endolymphatic duct are visible on dermal and visceral surfaces; those on the visceral surface are surrounded by a supraotic thickening. A median occipital crest divides the caudal surface. Like the nuchals, the laterals are small and shallow; each preserves the path of the infraorbital pit-line groove and the central pit-line groove that continues from the nuchal. The visceral surface of these laterals shows the rostrolateral extensions of the otic-occipital depression on the nuchal plates, pre- and post-lateral cristae and the transverse rostral groove between them. All ten of the cephalic skeletal plates from NV2K15, including the premedian plate, have a reticulating ornament.

Localities along the eastern and western shores of Goose Fiord's upper reaches have produced antiarch fossils during the recent (1999-2014) paleontological expeditions and during the Norwegian 2nd Fram expedition of 1898-1902. Per Schei collected material representing at least two species of antiarch from Galge Valley (head of the fiord) and Skrap Valley (western shore). Four specimens (PMO A13305, partial anterior ventrolateral plate; $\mathrm{PMO}$ A13403, possible anterior dorsolateral plate; PMO A13045, impression of a possible posterior ventrolateral plate; PMO A13169, possible dorsal central 1 plate) belong to a single size category and were described by Kiaer (1915) as Bothriolepis cf. hydrophila and redescribed as Bothriolepididae indet. by Downs et al. (2016). Kiaer (1915) described a fifth specimen of a larger size category (PMO A13050, fragment of possible anterior ventrolateral plate) as Bothriolepis ? sp.; this specimen was redescribed by Downs et al. (2016) as Antiarchi indet. Recent collecting along the eastern shore of the fiord has yielded a proximal end of a pectoral appendage (NUFV 1303) from NV2K07; fragments of anterior ventrolateral plates, dorsal/ventral central 1 plate, and other plates from NV2K02 (NUFV 1020); and three partial cephalic skeletons (NUFV 1304-1306), one each from localities NV2K01, NV2K05, and NV2K07.

The most complete of the three partial cephalic skeletons (NUFV 1305 from NV2K05; Fig. 9K, L) is diagnosed as Bothriolepididae sp. indet. by a nuchal plate that contributes to the orbital margin (Lukševičs 2001). This cephalic skeleton has an approximate width/length index of 128 , close to the lower end of the range of indices cited for Bothriolepis canadensis (130-152, Stensiö 1948; Béchard et al. 2014). The premedian plate is especially long and narrow (width/length index is approximately 83) and the preorbital recess (Fig. 9L'[po.r]), when correcting for a break in the specimen, seems to have a horizontal rostral margin. The ornament of the cephalic skeleton is dominated by reticulating ridges caudally and anastomosing ridges rostrally. Other features of the cephalic skeleton (infraorbital and central pit-line grooves, obtected margin, supraoccipital pits, otic-occipital depression, pre- and postlateral cristae) are as expected for Bothriolepis.

The second partial cephalic skeleton (NUFV 1304 from NV2K01), preserved in external view, is smaller and less complete than the first but it too may be diagnosed as Bothriolepididae sp. indet. according to the nuchal contribution to the orbital margin (Lukševičs 2001). General dimensions and ornament suggest the specimen may belong to the same species as the first described above. The third partial cephalic skeleton (NUFV 1306 from NV2K07) is an articulated partial premedian and partial lateral plate preserved in external view. The ornament is made of reticulating ridges. 

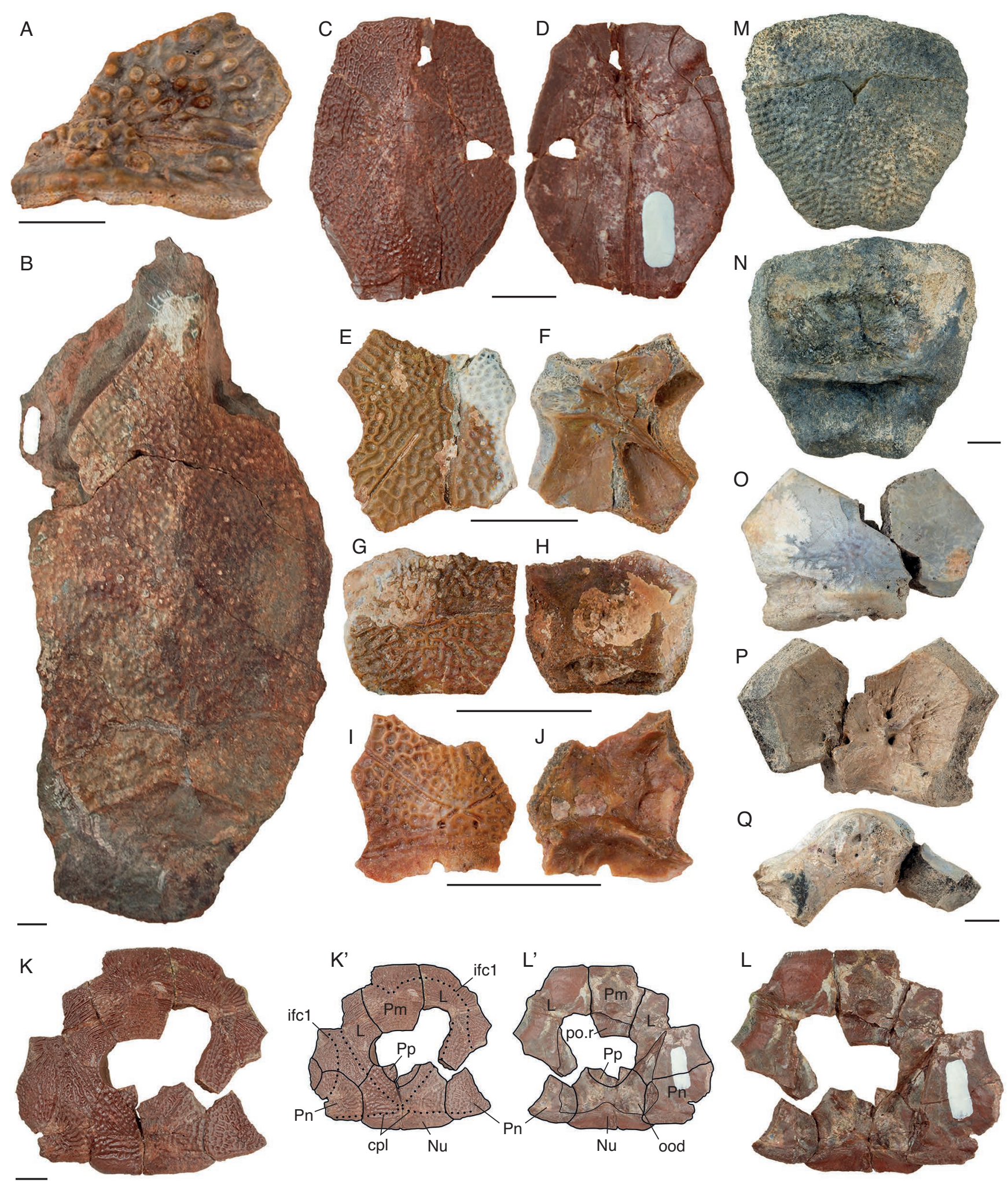

FIG. 9. - Antiarchi material from Devonian deposits of Nunavut. A, Asterolepidoidei sp. indet. from NV0207, NUFV 1280, nuchal plate in dermal view; B, Asterolepis sp. indet. from NV0205, NUFV 1287, anterior median dorsal plate in dermal view; C, D, Bothriolepis sp. indet. from NV2K17, NUFV 847, anterior median dorsal plate in dermal (C) and visceral (D) views; E-J, Bothriolepididae sp. indet. from NV2K15, E, F, NUFV 1296, right lateral plate in dermal (E) and visceral (F) views; G, H, NUFV 1295, premedian plate in dermal (G) and visceral (H) views; I, J, NUFV 1302, nuchal plate in dermal (I) and visceral (J) views; K, L, Bothriolepididae sp. indet. from NV2K05, NUFV 1305, articulated partial cephalic skeleton in dermal (K, photograph; K', labeled illustration) and visceral (L, photograph; L', labeled illustration) views; M, N, Bothriolepidoidei sp. indet. from NV9913, NUFV 1308, premedian plate in dermal (M) and visceral (N) views; O-Q, Asterolepidoidei sp. indet. from NV9917, NUFV 1307, nuchal plate in dermal (O), visceral (P), and caudal (Q) views. Abbreviations: cpl, central pit-line groove; ifc1, principal section of infraorbital pit-line groove; L, lateral plate; Nu, nuchal plate; ood, otic-occipital depression; Pm, premedian plate; Pn, paranuchal plate; po.r, preorbital recess; Pp, postpineal plate. Scale bars: $1 \mathrm{~cm}$. 
The antiarch fossils of the Fram Formation generally conform to the geographically inconsistent, but traditional, notion of Bothriolepididae replacing Asterolepididae sometime in the Middle to Late Devonian. This was first recognized in the Old Red Sandstone of Western Europe (Traquair 1895; Westoll 1951) and has since been extended to include the Baltics and Leningrad region of Russia, northwestern Australia, and western United States (Young 1974). The antiarch material from localities low in the Fram Formation (near Vendom and Sor Fiords) is diagnosable to Asterolepidoidei sp. indet. and Asterolepis sp. indet. In the middle Fram Formation localities of the Bird Fiord valley, both bothriolepidids and asterolepidids are recognized and even appear together at a single locality (NV2K17). The antiarchs from the highest Fram Formation localities (along both shores of Goose Fiord) all belong to Bothriolepididae. If such a turnover in the antiarch fauna took place in this geographic location, it may have happened during the deposition of the Fram Formation. The Ellesmere Island fossils thus far recovered promote the middle part of the Fram Formation (early middle Frasnian) as the local time of such a faunal turnover.

Note. In addition to the Fram Formation localities of Ellesmere Island, we have also recovered antiarch fossils from the western islands of Melville Island and Ile Vanier. The Melville Island localities are in the Beverley Inlet Formation, a stratigraphic unit that is laterally equivalent to the Fram, Hell Gate, and Nordstrand Point Formations of the Okse Bay Group (Frasnian; Embry 1991). Harrison \& de Freitas (1998) map the Ile Vanier localities as Cape Fortune Member of the Parry Islands Formation (Famennian; Embry 1991), but our biostratigraphic and lithological observations are inconsistent with this identification. Instead, we suggest that these localities are within the Beverly Inlet Formation (Frasnian; Embry, 1991). Of note, among the antiarch material from Ile Vanier, there is a bothriolepidoid premedian plate (NUFV 1308 from NV9913; Fig. 9M, N) that is diagnosed by the preorbital recess (Moloshnikov 2008), and an asterolepidoid nuchal (NUFV 1307 from NV9917; Fig. 9O-Q) that is diagnosed by the lack of orbital margin (Moloshnikov 2008). These two specimens were recovered from stratigraphically equivalent localities (asterolepidoid from NV9917; bothriolepidoid from NV9913). Both specimens are remarkable for their large size and their skeletal thickness, and are unlike any of the Fram Formation antiarchs that are described above.

\section{Acknowledgements}

We thank C F. Mullison for fossil preparation; S. Bunson for photography, illustrations, and figure compilation; and J. Stefl and R. Evenden for curatorial support. K. Manahan acquired difficult-to-find historical references. S. Olive provided helpful discussion. Two anonymous referees also helped to improve a previous version of the manuscript. We thank the Nunavut Ministry of Culture, Language, Elders and Youth and the Grise Fiord Hamlet and Hunters and Trappers Association for providing permits that made this research possible. The
Polar Continental Shelf Project provided logistical support and the Canadian Museum of Nature provided collections support. The authors recognize everyone who has provided field assistance on the Nunavut Paleontological Expeditions (1999-2014). This research was supported by two anonymous donors; the Academy of Natural Sciences of Philadelphia; the Putnam Expeditionary Fund (Harvard University); the University of Chicago; the National Science Foundation grants EAR 0207721 (EBD), EAR 0544093 (EBD), EAR 0208377 (NHS), and EAR 0544565 (NHS); the National Geographic Society Committee for Research and Exploration grants 7223-02, 7665-04, 8040-06, and 8420-08.

\section{REFERENCES}

Agassiz L. 1844. - Monographie des Poissons Fossiles du Vieux Grès Rouge ou Système Dévonien (Old Red Sandstone) des îles Britanniques et de Russie. Soleure, Neuchâtel, 171 p. (in French). https://doi. org/10.5962/bhl.title.5752

Béchard I., Arsenault F. Cloutier R. \& Kerr J. 2014. — The Devonian placoderm fish Bothriolepis canadensis revisited with three-dimensional digital imagery. Paleontologia Electronica 17: 2A.

CHI B. I. \& Hills L. V. 1976. - Biostratigraphy and taxonomy of Devonian megaspores, Arctic Canada. Bulletin of Canadian Petroleum Geology 24: 640-818.

Cope E. D. 1885. - The position of Pterichthys in the system. American Naturalist 19: 289-291. https://doi.org/10.1086/273910

Daeschler E. B., Shubin N. H. \& Jenkins JR F. A. 2006. - A Devonian tetrapod-like fish and the evolution of the tetrapod body plan. Nature 440: 757-763. https://doi.org/10.1038/nature04639

Downs J. P., DAeschler E. B., Shubin N. H. \& Jenkins Jr. F. A. 2008. - The cranial endoskeleton of Tiktaalik roseae. Nature 455: 925-929. https://doi.org/10.1038/nature07189

Downs J. P., Daeschler E. B., Jenkins JR. F. A. \& Shubin N. H. 2011a. - A new species of Laccognathus (Sarcopterygii, Porolepiformes) from the Late Devonian of Ellesmere Island, Nunavut, Canada. Journal of Vertebrate Paleontology 31 (5): 981996. https://doi.org/10.1080/02724634.2011.599462

Downs J. P., CRISWELL K. E. \& DAesChler E. B. 2011b. — Mass mortality of juvenile antiarchs (Bothriolepis sp.) from the Catskill Formation (Upper Devonian, Famennian Stage), Tioga County, Pennsylvania. Proceedings of the Academy of Natural Sciences of Philadelphia 161: 191-203. https://doi.org/10.1635/053.161.0111

Downs J. P., Daeschler E. B., Jenkins JR. F. A. \& Shubin N. H. 2013. - Holoptychius bergmanni sp. nov. (Sarcopterygii, Porolepiformes) from the Upper Devonian of Nunavut, Canada, and a review of Holoptychius taxonomy. Proceedings of the Academy of Natural Sciences of Philadelphia 162: 47-59. https://doi. org/10.1635/053.162.0104

Downs J. P., Daeschler E. B., Garcia V. E. \& Shubin N. H. 2016. - A new large-bodied species of Bothriolepis (Antiarchi) from the Upper Devonian of Ellesmere Island, Nunavut, Canada. Journal of Vertebrate Paleontology 36 (6): e1221833. https://doi. org/10.1080/02724634.2016.1221833

Downs J. P., Daeschler E. B., LONG A. M. \& Shubin N. H. 2018. - Eusthenopteron jenkinsi sp. nov. (Sarcopterygii, Tristichopteridae) from the Upper Devonian of Nunavut, Canada, and a review of Eusthenopteron taxonomy. Breviora 562: 1-24. https://doi.org/10.3099/MCZ44.1

EICHWALD E. 1840a. — Die Tier und Pflanzenreste des alten rothen Sandsteins und Bergkalks in Novogrodischen Gouvernement. Bulletin Scientifique publié par l'Académie Impériale des Sciences de Saint-Petersbourg et rédigé par son Secrétaire perpétuel $7(6,7)$ : 78-91 [in German]. 
EICHWALD E. 1840b. - Geognostische Uebersicht von Esthland und den Nachbar-Gegenden. Neues Jahrbuch für Mineralogie, Geognosie, Geologie und Petrefakten-Kunde 1840: 421-430 [in German].

Elliott D. K. \& Petriello M. A. 2011. - New poraspids (Agnatha, Heterostraci) from the Early Devonian of the Western United States. Journal of Vertebrate Paleontology 31 (3): 518-530. https://doi.org/10.1080/02724634.2011.557113

Elliott D. K., Dineley D. L., \& Johnson H. G. 2000. — A vertebrate fauna from the Middle Devonian Yahatinda Formation of Southwestern Canada. Journal of Paleontology 74 (1): 123-132. https://doi.org/10.1017/S0022336000031309

EmbrY A. F. 1988. - Middle-Upper Devonian sedimentation in the Canadian Arctic Islands and the Ellesmerian Orogeny, in Mcmillan N. J., Embry A. F. \& Glass D. J. (eds), Canadian Society of Petroleum Geologists Memoir 14 (2). Canadian Society of Petroleum Geologists, Calgary: 15-28.

Embry A. F. 1991. — Middle-Upper Devonian Clastic Wedge of the Arctic Islands, in TreTTIN H. P. (ed), Geology of the Innuitian Orogen and Arctic Platform of Canada and Greenland. Geological Survey of Canada, Ottawa and Calgary: 263-279. https://doi. org/10.4095/133959

Embry A. \& Klovan J. E. 1976. — The Middle-Upper Devonian Clastic Wedge of the Franklinian Geosyncline. Bulletin of Canadian Petroleum Geology 24: 485-639.

Esin D., GinTer M., IVANOV A., Lebedev O., LuKSEVICs E., AvKHIMOVICH V., GolubTsov V. \& PeTuKhova L. 2000. - Vertebrate correlation of the Upper Devonian and Lower Carboniferous on the East European Platform. Courier Forschungsinstitut Senckenberg 223: 341359.

Gross W. 1931. - Asterolepis rnate Eichw. Und das Antiarchiproblem. Palaeontographica Abteilung A. Band 75. Lieferung 1-2: 1-62 [in German].

Gross W. 1933. - Die Fische des Baltischen Devons. Palaeontographica Abteilung A. Band 79. Lieferung 1-2: 1-74 [in German].

Gross W. 1940. - Acanthodier und Placodermen aus den Heterostius-Schichten Estlands und Lettlands. Tartu Ülikooli juures oleva Loodusuurijate Seltsi Aruanded 46: 12-99 [in German]. http://hdl.handle.net/10062/29055

Gross W. 1965. — Über die Placodermen-Gattungen Asterolepis und Tiaraspis aus dem Devon Belgiens und einen fraglichen Tiaraspis-Rest aus dem Devon Spitzbergens. Bulletin de l'Institut royal des Sciences naturelles de Belgique 41 (16): 1-19 [in German].

Harrison J. C. \& De Freitas T. 1998. — Bedrock geology, Helena Island (NTS B and 79A), Bathurst Island Group, District of Franklin, Northwest Territories (Nunavut). Geological Survey of Canada, Open File 3577. Scale 1:125,000 [map].

HiLls E. S. 1929. - The geology and palaeontography of the Cathedral Range and Blue Hills in north-western Gippsland. Proceedings of the Royal Society of Victoria 41: 176-201. https:// biodiversitylibrary.org/page/54367530

JANVIER P. 1979. - Les vertébrés dévoniens de l'Iran central. III: Antiarches. Geobios 12 (4): 605-608 [in French]. https://doi. org/10.1016/S0016-6995(79)80150-3

Janvier P. \& Villarroel C. 2000. - Devonian vertebrates from Colombia. Palaeontology 43 (4): 729-763. https://doi. org/10.1111/1475-4983.00147

Janvier P., Racheboeuf P., Nguyen Huu H., \& Doan Nhat T. 2003. - Devonian fish (Placodermi, Antiarcha) from the Tra Ban Island (Bai Tu Long Bay, Quang Ninh, Vietnam) and the question of the age of the Do Son Formation. Journal of Asian Earth Sciences 21 (7): 795-801. https://doi.org/10.1016/S13679120(02)00094-9

Karatajüte-Talimaa V. N. 1963. - Genus Asterolepis from the Devonian beds of the Russian Platform in GRIGELIS A. \& KARATAJÜTe-TalimaA V. N. (eds), The Data of Geology of The Lithuania. Vilnius. The Academy of Sciences of the Lithuanian SSP, The Geological and Geographical Institute: 65-224 [in Russian].
KIAER J. 1915. — Upper Devonian fish remains from Ellesmere Land with remarks on Drepanaspis: Report of the Second Norwegian Arctic Expedition in the "Fram" 1898-1902. Videnskabs-Selskabet i Kristiana. Brøgger's and Christie's, Oslo, 53 p. https:// biodiversitylibrary.org/page/37788015

LONG J. A. 1983. - New bothriolepid fish from the Late Devonian of Victoria, Australia. Palaeontology 26 (2): 295-320. https:// biodiversitylibrary.org/page/49741248

LUKŠEVIČs E. 2001. - The orbito-nasal area of Asterolepis ornata, a Middle Devonian placoderm fish. Journal of Vertebrate Paleontology 21 (4): 687692. https://doi.org/10.1671/0272-4634(2001)021[0687:TON $\mathrm{AOA}] 2.0 . \mathrm{CO} ; 2$

LYARSKAJA L. A. 1981. - Baltic Devonian Placodermi: Asterolepididae. Zinatne, Riga, Latvia, 152 p. [in Russian with English summary].

MaYr U. 1994. — Regional geology, in MAYr U., PACKARD J. J., Goodbody Q. H., Okulitch A. V., Rice R. J., Goodarzi F. \& STEWART K. R. (eds), The Phanerozoic Geology of Southern Ellesmere and North Kent Islands, Canadian Arctic Archipelago. Geological Survey of Canada, Ottawa and Calgary: 12-16.

Miles R. S. 1968. - The Old Red Sandstone antiarchs of Scotland: family Bothriolepididae. Palaeontological Society Monographs 122 (522): 1-130.

Miller J. H., Shubin N., Daeschler E. \& Downs J. 2007. - Stratigraphic context of Tiktaalik roseae (Late Devonian): paleoenvironment of the fish-tetrapod transition. Geological Society of America Meeting, Denver, Colorado, 28-31 October 2007. Abstracts and Programs 39: 417.

MOLOSHNIKOV S. 2004. - Crested antiarch Bothriolepis zadonica H. D. Obrucheva from the Lower Famennian of Central European Russia. Acta Palaeontologica Polonica 49 (1): 135-146.

Moloshnikov S. 2008. - Devonian antiarchs (Pisces, Antiarchi) from Central and Southern European Russia. Paleontological Journal 42 (7): 691-773. https://doi.org/10.1134/S0031030108070010

Moloshnikov S. 2012. - Middle-Late Devonian Placoderms (Pisces: Antiarchi) from Central and Northern Asia. Paleontological Journal 46 (10): 1097-1196. https://doi.org/10.1134/ S0031030112100012

Murphy M. A., Morgan T. G. \& Dineley D. L. 1976. - Astrolepis sp. from the Upper Devonian of Central Nevada. Journal of Paleontology 50 (3): 467-471. https://www.jstor.org/stable/1303528

Newman M. J. \& Den BlaauWen J. L. 2018. - A redescription of the endemic antiarch placoderm Asterolepis thule from the Middle Devonian (Givetian) of Shetland and its biostratigraphical horizon. Scottish Journal of Geology https://doi.org/10.1144/sjg2018-005

OBRUCHEV D. 1933. - Description of four new species of fish from the Devonian of Leningrad Province. Materials of the Central Scientific Geological and Prospecting Institute. Paleontology and Stratigraphy Magazine 1: 12-15 [in Russian].

Olive S. 2015. - Devonian antiarch placoderms from Belgium revisited. Acta Palaeontologica Polonica 60 (3): 711-713. https:// doi.org/10.4202/app.00015.2013

RoHON J. V. 1899. — Die devonischen fische von Timan in Russland. Sitzungsberichte der königlische böhmischen Gesellschaft der Wissenschaften. Mathematisch-naturwissenschaftliche Classe 8: 1-77 [in German].

SCHultze H.-P. 2010. - The late Middle Devonian fauna of Red Hill I, Nevada, and its paleobiogeographic implications. Fossil Record 13 (2): 285-295. https://doi.org/10.1002/mmng.201000001

SCOTESE C. R. \& MCKERROW W. S. 1990. — Revised world maps and introduction. Geological Society Memoir 12: 1-21. https:// doi.org/10.1144/GSL.MEM.1990.012.01.01

Shubin N. H., Daeschler E. B. \& Jenkins JR. F. A. 2006. - The pectoral fin of Tiktaalik roseae and the origin of the tetrapod limb. Nature 440: 764-771. https://doi.org/10.1038/nature04637

STENSIÖ E. A. 1931. - Upper Devonian vertebrates from East Greenland collected by the Danish Greenland expeditions in 1929 and 1930. Meddelelser om Grønland 86 (1): 1-212. 
STENSIÖ E. A. 1948. — On the Placodermi of the Upper Devonian of East Greenland II. Meddelelser om Gronland 139: 1-622.

STENSIÖ E. A. \& SÄVE-SöDERBERGH G. 1938. — Middle Devonian vertebrates from Canning Land and Wegener Peninsula (East Greenland). Meddelelser om Grønland 96: 1-38.

TRAQUAIR R. H. 1888. - On the structure and classification of the Asterolepidae. Proceedings of the Royal Physical Society of Edinburgh 10: 23-46. https://biodiversitylibrary.org/page/25123533

TRAQUAIR R. H. 1895. - The extinct vertebrate animals of the Moray Firth area in HARVIE-BROWN J. A. \& BUCKLEY T. A. (eds), A Vertebrate Fauna of the Moray Firth Basin. Volume 2. T. and A. Constable, Edinburgh: 235-285. https://doi.org/10.5962/ bhl.title.69239

Traquair R. H. 1914. - The fishes of the Old Red Sandstone of Britain. Part II - The Asterolepidae, in LANKESTER E. R., Traquair R. H. \& POWrie J. (eds), A Monograph of the Fishes of the Old Red Sandstone of Britain. Palaeontographical Society, London, England: 10-134.

UPENIECE I. 2011. - Palaeoecology and juvenile individuals of the Devonian placoderm and acanthodian fishes from Lode site, Latvia. (Doctoral dissertation). Retrieved from https://dspace. lu.lv/dspace/handle/7/4659 (last access on $3^{\text {rd }}$ October 2019).

UPENIECE I. \& UPENIEKS J. 1992. - Young Upper Devonian antiarch (Asterolepis) individuals from the Lode quarry, Latvia, in MArK-KuriK E. (ed.), Academia 1. Fossil Fishes as Living Organisms. Academy of Sciences of Estonia, Tallinn: 167-176.

WATSON D. M. S. 1932. - On three new species of fish from the Old Red Sandstone of Orkney and Shetland, in Summary of Progress of the Geological Survey of Great Britain and the Museum of Practical Geology for the Year 1931. Part II. His Majesty's Stationery Office, London, England: 157-163.

Wells J. W. 1964. - The antiarch Asterolepis in the Upper Devonian of New York. Journal of Paleontology 38 (3): 492495. https://www.jstor.org/stable/1301525

WeSTOLL T. S. 1951. - The vertebrate-bearing strata of Scotland. Report of the XVIII International Geological Congress of Great Britain, Proceedings of Section $K$ : The correlation of continental vertebrate-bearing rocks 11: 5-21.

WoOdward A. S. 1891. - The Devonian fish-fauna of Spitsbergen. The Annals and Magazine of Natural History, series 6 , 8 (43): 1-15. https://biodiversitylibrary.org/page/ 19244677

YounG G. C. 1974. - Stratigraphic occurrences of some placoderm fishes in the Middle and Late Devonian. Newsletters on Stratigraphy 3 (4): 243-261. https://doi.org/10.1127/nos/3/1974/243

YounG G. C. 1984. - Reconstruction of the jaws and braincase in the Devonian placoderm fish Bothriolepis. Palaeontology 27: 635-660. https://biodiversitylibrary.org/page/49742174

YounG G. C. 1987. - Devonian fish remains from Billiluna, eastern Canning Basin, Western Australia. BMR Journal of Australian Geology and Geophysics 10 (2): 179-192.

Young G. C. 1993. - Middle Palaeozoic macrovertebrate biostratigraphy of Eastern Gondwana, in LoNG J. A. (ed.), Palaeozoic Vertebrate Biostratigraphy and Biogeography. Belhaven Press, London: 208-251.

Young G. C. \& Gorter J. D. 1981. - A new fish fauna of Middle Devonian age from the Taemas/Wee Jasper region of New South Wales. Bulletin/Bureau of Mineral Resources, Geology and Geophysics 209: 83-147. 